\title{
ANALISIS KEMAMPUAN METAKOGNISI DALAM PEMECAHAN MASALAH MATEMATIS PADA PEMBELAJARAN BERBASIS MASALAH DITINJAU DARI GAYA BELAJAR
}

\author{
Khairatun Nisa Rambe ${ }^{1}$, Bornok Sinaga ${ }^{2}$, Asmin $^{2}$
}

\begin{abstract}
ABSTRAK
Penelitian ini bertujuan untuk menganalisis dan mengetahui: (1) tingkat kemampuan metakognisi dalam pemecahan masalah matematis ditinjau dari gaya belajar siswa pada pembelajaran berbasis masalah; (2) proses jawaban metakognisi siswa dalam pemecahan masalah matematis ditinjau dari gaya belajarnya pada pembelajaran berbasis masalah; (3) kesulitan metakognisi yang dialami siswa dalam pemecahan masalah matematis ditinjau dari gaya belajarnya pada pembelajaran berbasis masalah. Penelitian ini merupakan penelitian kualitatif deskriptif. Subjek penelitian ini adalah siswa MTs Negeri 1 Labuhanbatu Selatan yang berjumlah 34 orang.

Adapun hasil penelitian sebagai berikut: (1) Terdapat 7 orang $(23,52 \%)$ siswa dengan gaya belajar pragmatis, siswa dengan kemampuan tinggi, berada pada tingkat kemampuan metakognisi strategic use, siswa berkemampuan sedang, berada pada tingkat kemampuan metakognisi aware use, dan siswa berkemampuan rendah, berada pada tingkat kemampuan metakognisi tacit use; Terdapat 13 orang $(44,11 \%)$ siswa dengan gaya belajar reflektor, siswa dengan kemampuan tinggi berada pada tingkat metakognisi reflective use dan strategic use. Siswa berkemampuan sedang, berada pada tingkat kemampuan metakognisi aware use, dan siswa berkemampuan rendah, berada pada tingkat kemampuan metakognisi tacit use; Terdapat 10 siswa (32,35\%) dengan gaya belajar teoris, siswa dengan kemampuan sedang, berada pada tingkat kemampuan metakognisi aware use, dan siswa berkemampuan rendah, berada pada tingkat kemampuan metakognisi tacit use; dan terdapat 4 orang siswa dengan gaya belajar aktivis. (2) Kesulitan siswa dengan gaya belajar pragmatis, siswa mengalami kesulitan pada aspek konsep, prinsip, dan prosedur. Kesulitan siwa dengan gaya belajar reflektor, siswa mengalami pada aspek prinsip, dan prosedur; Kesulitan siswa dengan gaya belajar teoris, siswa mengalami fakta, konsep dan prinsip; dan Kesulitan siswa dengan gaya belajar aktivis, siswa mengalami kesulitan fakta, konsep, dan prosedur.
\end{abstract}

Kata Kunci: Kemampuan Metakognisi, Pemecahan Masalah, Model Pembelajaran Berbasis Masalah, Gaya Belajar Honey \& Mumford

\section{PENDAHULUAN}

Saragih \& Napitupulu (2015) menyatakan bahwa Matematika penting untuk diajarkan oleh siswa karena matematika selalu digunakan dalam kehidupan seharihari siswa. Siswa diharapkan dapat menggunakan matematika dan pola pikir matematika dalam kehidupan sehari-hari, dan juga kemampuan untuk menerapkan matematika. Tujuan pembelajaran matematika adalah untuk dapat memahami konsep, mempraktikkan penalaran matematika, menyelesaikan masalah, mengkomunikasikan ide-ide dalam bentuk simbol, tabel, diagram atau lainnya, dan mengembangkan sikap siswa dalam mengapresiasi kegunaan matematika dalam kehidupan sehari-hari. Saat ini, pemecahan masalah adalah fokus dalam belajar matematika. Kemampuan pemecahan masalah menurut Syahputra, Panjaitan, Surya \& Lubis (2017) adalah kemampuan atau kompetensi strategis yang ditunjukkan oleh siswa dalam memahami, memilih pendekatan dan strategi koping serta model yang lengkap untuk menemukan solusi untuk masalah.

${ }^{1}$ Corresponding Author: Khairatun Nisa Rambe

Program Magister Pendidikan Matematika, Universitas Negeri

Medan, Medan, 20221, Indonesia

E-mail: khairatunnisarambe@gmail.com

${ }^{2}$ Co-Author: Bornok Sinaga \& Asmin

Program Studi Pendidikan Matematika, Universitas Negeri Medan, Medan, 20221, Indonesia
Pemecahan masalah adalah bagian dari kurikulum matematika yang sangat penting untuk diterapkan dalam menyelesaikan masalah yang tidak secara rutin dibutuhkan dalam kehidupan sehari-hari (Mulyono \& Hadiyanti, 2018). Pemecahan masalah adalah bagian penting dari pembelajaran matematika dan sangat membantu ketika siswa menghadapi masalah dan melihat masalah yang harus dipecahkan (Karatas \& Baki, 2017). Karenanya penyelesaian masalah memiliki peran penting dalam pembelajaran matematika dan bahkan menjadi pusat atau fokus dalam pembelajaran matematika.

Dalam kaitannya dengan pemecahan masalah, ada 3 aspek yang berkontribusi terhadap pemecahan masalah matematika menurut Charles dan Lester, yaitu: (1) aspek kognitif, termasuk pengetahuan konseptual, pemahaman dan strategi untuk menerapkan pengetahuan itu; (2) aspek afektif, yaitu aspek yang mempengaruhi kecenderungan siswa untuk menyelesaikan masalah; dan (3) aspek metakognisi, termasuk kemampuan untuk mengatur pemikiran sendiri. Metakognisi dari perspektif pendidikan mengacu pada pengetahuan dan pemantauan seseorang dan pengendalian aktivitas kognitif seseorang yang membutuhkan keterampilan metakognitif tertentu seperti perencanaan dan evaluasi (Alzahrani, 2015). Menurut Anderson \& Krathwohl (2001) bahwa pengetahuan metakognisi adalah pengetahuan tentang 
kognisi, umumnya sama dengan kesadaran dan pengetahuan tentang kognisi diri seseorang. Dapat disimpulkan bahwa metakognisi adalah pemikiran seseorang tentang apa yang ia pahami, apa yang diketahui dan apa yang diingat termasuk kesadaran dan kontrol atas proses kognisi yang dilakukan.

Dalam perkembangannya, pendidikan di Indonesia menghadapi beberapa permasalahan. Adapun permasalahan yang muncul mulai dari input, proses dan output. Baik input, proses maupun output ketiganya saling terkait satu sama lain. Input mempengaruhi keberlanjutan dalam proses pembelajaran. Proses pembelajaranpun turut mempengaruhi hasil output. Dan selanjutnya output akan kembali berlanjut ke input (Megawati, 2015).

Hasil evaluasi terhadap siswa-siswa SMP dan sekolah menengah di Amerika Serikat seperti yang di ungkapkan oleh Cleinents dan Battista (1992) menggambarkan bahwa mereka gagal mempelajari konsep dasar geometri.. Rendahnya penguasaan materi geometri tidak hanya terjadi pada siswa-siswa, tetapi juga terjadi pada guru-guru matematika sekolah menengah. Pembelajaran geometri di sekolah sebaiknya diarahkan pada penyelidikan dan pemanfaatan ide-ide serta hubungan-hubungan antara sifat-sifat geometri. Dalam belajar geometri siswa diharapkan dapat memvisualisasikan, menggambarkan serta membandingkan bangun-bangun geometri dalam berbagai posisi, sehingga murid dapat memahaminya.

Metakognisi dalam penyelesaian masalah adalah hal penting yang perlu mendapatkan perhatian dari pendidik, terutama untuk membantu siswa mengembangkan kemampuan mereka untuk memecahkan masalah. Oleh karena itu, metakognisi memiliki perannya sendiri dalam proses pembelajaran matematika, terutama dalam pemecahan masalah. Di mana siswa akan menyadari proses pemikiran mereka dan mengevaluasi diri mereka sendiri terkait dengan hasil proses pemikiran mereka. Sehingga dimungkinkan untuk meminimalkan kesalahan siswa dalam menyelesaikan atau menyelesaikan masalah.

Fakta yang peneliti temukan ketika memberikan masalah pemecahan masalah matematika dengan pertanyaan kemampuan metakognisi kepada siswa kelas VIII Shiddiq, MTs Negeri 1 Labuhanbatu Selatan, sebenarnya menunjukkan bahwa siswa mengalami kesulitan dalam memecahkan masalah dalam bentuk pemecahan masalah dan menghubungkan mereka dalam kehidupan sehari-hari. Berdasarkan jawaban siswa terlihat kesalahan dalam proses jawaban siswa dalam melakukan latihan kognitif yang menghasilkan kesalahan dalam pemecahan masalah. Dimana kemampuan metakognisi siswa yang rendah, dampaknya pada pemecahan masalah oleh siswa akan kurang baik. Oleh karena itu kemampuan metakognisi dalam matematika perlu dilatih dan dibiasakan dengan siswa sedini mungkin. Kemampuan ini dibutuhkan oleh siswa sebagai bekal dalam menyelesaikan masalah matematika dan masalah yang ditemukan dalam kehidupan sehari-hari.

Beberapa penelitian yang mendukung bahwa tidak semua siswa dapat menggunakan keterampilan metakologis mereka dengan baik dalam memecahkan masalah matematika, termasuk penelitian Rawa (2017) menunjukkan bahwa hasil pemecahan masalah siswa PGSD dalam hal gaya belajar Introvert dan ekstrovert, tingkat metakognisi siswa dengan gaya belajar ekstrovert berada dalam kategori penggunaan strategis dan penggunaan sadar, di mana penggunaan pikirannya baik sebelum dan sesudah atau bahkan selama proses kurang mempertimbangkan kelanjutan dan peningkatan hasil pemikirannya, sehingga ada beberapa masalah matematika yang tidak persis hasil perhitungannya. Rendahnya kemampuan metakognisi juga dapat dilihat dari hasil penelitian yang menunjukkan bahwa pada setiap tingkat metakognisi dalam menyelesaikan masalah cerita, siswa berkemampuan tinggi yang memiliki keterampilan metakognitif tinggi dapat melewati tahap metakognisi dengan benar sesuai dengan indikator. Tetapi untuk kemampuan rendah siswa memiliki tingkat kelengkapan kegiatan metakognisi yang rendah juga. Rendahnya kemampuan siswa dalam melewati tahapan perilaku metachogical masih kurang, karena ada beberapa indikator yang tidak dipenuhi olehnya. Seperti tahap analisis dan inspeksi. Berdasarkan hasil penelitian ini menunjukkan bahwa tidak semua siswa dapat menggunakan kemampuan metachogis mereka dengan baik, mengidentifikasi kesulitan metakognitif yang dialami oleh siswa dalam menyelesaikan masalah.

Salah satu yang mempengaruhi keterampilan metakognitif siswa dalam memecahkan masalah matematika adalah gaya belajar. Menurut Rahmawati (2015) bahwa berbagai penelitian telah menunjukkan bahwa banyak siswa mengalami kesulitan dalam belajar matematika dan lemah dalam prestasi di bidang matematika seperti kemampuan metakogis siswa dalam pemecahan masalah. Ada banyak faktor dan variabel yang mempengaruhi, antara lain, gaya belajar, kecemasan matematika, kurang percaya diri, kepercayaan guru, lingkungan, kurangnya perhatian orang tua, dan jenis kelamin.

Setiap siswa memiliki gaya belajar yang berbeda dan setiap gaya belajar juga memiliki karakteristik yang berbeda. Oleh karena itu guru juga harus menganalisis gaya belajar setiap siswa sehingga informasi yang diperoleh guru dapat membantu guru memahami perbedaan di setiap siswa sehingga pembelajaran yang bermakna terjadi di lingkungan sekolah (di kelas). Jika seorang anak menangkap informasi / materi sesuai dengan gaya belajarnya sendiri, maka tidak akan ada pelajaran yang sulit. Barbara Prashning (Yeni, 2015) menyatakan bahwa penyerapan informasi tergantung pada bagaimana orang bekerja di dalamnya. Dengan demikian, dapat dikatakan bahwa karakteristik gaya belajar yang dimiliki oleh siswa adalah salah satu modal yang berpengaruh dalam pembelajaran, pengolahan, dan komunikasi.

Seorang individu belajar berdasarkan dua cara, pertama melalui proses belajar, dan yang kedua melalui pengalaman (Chatib, 2014). Menurut penelitian Carns \& Carns (1991) menunjukkan bahwa gaya belajar dapat digunakan untuk meningkatkan kemampuan 
metakognitif. Dari 118 siswa kelas 4 yang didiagnosis dengan gaya belajar, hasil tes diperoleh yang menunjukkan peningkatan skor / nilai. Beberapa penelitian terkait metakognisi dalam hal gaya belajar telah dilakukan di beberapa tingkat pendidikan, yaitu penelitian Syam, Ulfiani \& Nursalam (2016) ialah studi yang dilakukan di tingkat sekolah menengah pertama, dan penelitian Zulyanty, Ipung \& Makbul (2017) di tingkat sekolah menengah, dan di tingkat universitas. tinggi ditunjukkan dalam penelitian Rawa (2017). Semua studi ini fokus pada gaya belajar VAK (Visual, Audiotori, dan Kinesthetic) dan pada dimensi kepribadian introvert. Namun, dalam penelitian ini para peneliti fokus pada gaya belajar menurut Peter Honey dan Alan Mumford. Itu karena gaya belajar dikelompokkan berdasarkan cara siswa belajar dan bagaimana hal itu mempengaruhi pembelajaran (Honey \& Mumford, 1992).

Honey dan Mumford dalam Aljebri \& Gheith (2015) menggambarkan empat gaya belajar berdasarkan pengalaman sebagai berikut: (1) memiliki pengalaman (Aktivis); (2) pengalaman meninjau (Refelector); (3) kesimpulan dari pengalaman (Ahli Teori); dan (4) merencanakan langkah selanjutnya (Pragmatis). Aljebri (2015) menjelaskan bahwa gaya belajar mampu mempengaruhi kemampuan siswa dalam menyelesaikan masalah matematika, dan ada hubungan antara gaya belajar ini dengan setiap langkah dalam memecahkan masalah matematika Polya.

Guru sebagai fasilitator dalam pembelajaran harus memahami karakteristik siswa. Melalui pemahaman yang baik tentang karakteristik siswa, seorang guru dapat menentukan model, strategi, dan metode pembelajaran yang tepat. Pemilihan model, strategi, dan metode pembelajaran yang tepat dapat membantu guru mengundang siswa untuk belajar sehingga tujuan dari proses pembelajaran dapat tercapai. Suyono, \& Hariyanto (2015) menyatakan bahwa mengetahui gaya belajar itu penting karena mengetahui gaya belajar siswa dapat membantu mengoptimalkan jumlah pengetahuan yang diperoleh pada suatu waktu. Berdasarkan beberapa uraian di atas, penelitian ini dilakukan di kelas VII Tabligh MTs Negeri 1 Labuhanbatu untuk menganalisis kemampuan Metakognisi dalam Pemecahan Masalah Matematika dalam hal Gaya Belajar Siswa.

\section{KAJIAN TEORITIS}

\section{Pemecahan Masalah Matematis Masalah Matematis}

Nurdin (2012) menyatakan suatu pernyataan akan menjadi masalah jika pertanyaan itu menunjukkan adanya suatu tantangan (Chalenge) yang tidak dapat dipecahakan oleh suatu prosedur rutin (rutine procedure) yang sudah diketahui oleh si pelaku. Defenisi di atas mengandung implikasi bahwa suatu maslaah harus mengandung adanya "tantangan" dan "belum diketahui prosedur rutin". Prosedur rutin di sini adalah soal yang penyelesaiannya sudah bisa ditebak, diketahui rumusnya, dan dengan satu adatu dua langkah soal sudah bisa diselesaikan. Tim MKPBM
(2001: 86) menyatakan suatu masalah biasanya memuat suatu situasi yang mendorong seseorang untuk menyelesaikannya, akan tetapi tidak tahu secara langsung apa yang harus dikerjakan untuk menyelesaikannya. Jika suatu masalah diberikan kepada siswa dan siswa tersebut langsung mengetahui cara menyelesaikannya dengan benar, maka soal tersebut dapat dikatakan sebagai masalah.

Masalah matematika menurut Tomas Butts yang dikutip Nugrahaningsih (2011) dibedakan menjadi 5 jenis, yakni : (1) Recognition exercise merupakan masalah yang berkaitan dengan ingatan misalnya fakta, konsep, defenisi, dan pernyataan teorema; (2) Alghoritmic exercise merupakan masalah yang berkaitan penggunaan langkah demi langkah dari suatu prosedur atau cara tertentu; (3) Aplication Problems merupakan masalah yang ada penerapan algoritma. Sehingga untuk menyelesaikannya perlu memformulasikan maslah secara simbolik kemudian memanipulasi sismbol-simbol dan memilih algoritma tertentu yang sesuai; (4) Open Search Problems merupakan masalah yang penyelesaiannya tidak segera ditemukan startegi tertentu untuk menyelesaikan masalah, misalnya masalah pembuktian; (5) Problem Situation merupakan masalah yang berkaitan dengan kehidupan sehari-hari.

Dengan demikian, suatu maslaah dapat dipandang sebagai masalah merupakan hal yang relative. Dimana suatu soal dianggap sebagai masalah bagi seseorang, bagi orang lain mungkin hanya merupakan hal yang rutin belaka. Jadi, guru perlu berhati-hati dalam menentukan soal yang akan disajikan sebagai pemecahan masalah. Bagi sebagian besar guru, untuk memperoleh atau menyusun soal yang benar-benar bukan merupakan masalah rutin bagi siswa mungkin termasuk pekerjaan yang sulit.

\section{Pemecahan Masalah Matematis}

Dalam pembelajaran matematika pada dasarnya seseorang siswa tidak terlepas dari masalah. Wardhani, dkk (2010) menjelaskan bahwa memecahkan masalah matematika menurut Lencher merupakan proses menerapkan pengetahuan matematika yang telah diperoleh sebelumnya kedalam situasi baru yang belum dikenal. Branca (Krulik, 1980) menjelaskan pemecahan masalah dapat melatih siswa untuk membangun konsep atau pengetahuan, menemukan cara atau teknik penyelesaian yang baru, sehingga siswa dapat menyadari konsep atau pengetahuan yang benar dan menemukan strategi penyelesaian yang lebih efektif.

Adanya peningkatan kemampuan untuk menyelesaikan masalah, berarti siswa tersebut telah mengalami perubahan dalam tingkah lakunya, dengan demikian dalam pembelajaran matematika kemampuan memecahkan masalah sangat penting. Sesuai dengan pendapat yang dikemukakan oleh Suryadi dkk (Tim MKPBM, 2001 : 83) dalam surveynya tentang "Current situation on mathematical and science education in Bandung" antara lain menemukan bahwa pemecahan masalah matematik merupakan salah satu kegiatan matematik yang dianggap penting baik oleh para guru maupun siswa di semua tingkatan mulai dari Sekolah Dasar sampai Sekolah Menengah Atas. 
Vol. 13, No.2, Desember 2020

Dari uraian di atas dapat disimpulkan bahwa dalam pemecahan masalah siswa didorong dan diberi kesempatan seluas-luasnya untuk berinisiatif dan berpikir sistematis dalam mengahadapi suatu masalah dengna menerapkan pengetahuan yang didapat sebelumnya.

\section{Indikator Pemecahan Masalah Matematis}

Kemampuan memecahkan masalah merupakan salah satu kompetensi yang cukup penting bagi seseorang. Esensi kehidupan sehari-hari adalah situasi pemecahan masalah. Strategi dalam pemecahan masalah berisi seperangkat langkah-langkah penyelesaian dalam menemukan solusinya. Menurut Polya (1985) strategi tersebut yaitu memahami masalah, merencanakan pemecahan masalah, menyelesaikan masalah sesuai dengan penggunaan fungsi metakognisi. Hal tersebut dikarenakan, ketika siswa melakukan langkah-langkah pemecahan masalah akan timbul strategi-strategi pertanyaan yang dapat menyadarkan siswa tentang proses berpikirnya, bagaimaba masalah dihadapi, bagaimana cara untuk memeperoleh ide atau gagasan yang tepat dalam penyelesaiannya, membuat rencana penyelesaian, dan melakukan evaluasi dari hasil yang diperoleh.

Pada penelitian ini kemampuan pemecahan masalah yang digunakan adalah menurut Polya (1985) terdapat empat langkah pokok memecahkan suatu masalah, yakni:

1. Memahami masalah

2. Membuat rencana untuk menyelesaikan masalah

3. Melaksanakan penyelesaian soal

4. Memeriksan ulang jawaban yang diperoleh

Kegiatan yang dpaat dilakukan pada langlah ini adalah menganalisis dan mengevaluasi apakah prosedur yang ditetapkan dan hasil yang diperoleh benar, apakah ada prosedur lain yang lebih efeketif, apakah prosedur yang dibuat dapat digunakan untuk menyelesaikan masalah yang sejenis, atau apakah prosedur dapat dibuat generalisasinya.

Dari beberapa langkah atau tahapan pemecahan masalah yang dikemukakan, pada prinsipnya pemecahan masalah dilakukan secara teratur, logis, analitis, kritis, kreatif, sistematis atau procedural dan mutlak menggunakan serta menghubungkan pengetahuan yang suda mereka miliki sebelumnya, termasuk penggunaan fakta-fakta (berupa konvensi yang diungkapkan dengan symbol tertentu), konsepkonsep (ide abstrak yang dapat digunakan untuk menggolongkan atau mengklasifikasikan sekumpulan objek), operasi (proses pengerjaan, perhitungan, pengerjaan aljabar, dan pengerjaan matematika lainnya), dan prinsip (sekumpulan objek matematika yang kompleks, prinsip dapat terdiri atas beberapa fakta dan konsep yang dikaitkan oleh suatu relasi ataupun operasi).

Dengan demikian, inti dari belajar memecahkan masalah adalah agar peserta didik terbiasa mengerjakan soal-soal yang tidak hanya mengandalkan ingatan yang baik saja, tetapi peserta didik diharapkan dapat mengaitkan dengan situasi nyata yang pernah dialaminya atau yang pernah dipikirkannya. Kemudian peserta didik bereskplorasi dengan benda nyata, lalu akan memepelajari ide-ide matematika secara informal, selanjutnya belajar matematika secara formal.

Berdasarkan uraian diatas, kemampuan pemecahan masalah dalam penelitian ini merupakan suatu cara pembelajaran dengan menghadapkan siswa kepada suatu masalah kontekstual untuk dipecahakan atau diselesaikan. Langkah-langkah pemecahan masalah yang digunakan dalam penelitian ini mengacu kepada langkag yang dikemukakan oleh Polya, yakni aspek memehami masalah diukur melalui menuliskan informasi yang diketahui dari soal dan membandingkan soal mana yang lebih mudah, aspek merencanakan pemecahan diukur melalui menuliskan model atau persamaan matematika, aspek menyelesaikan masalah diukur melalui melaksanakan pemecahan sesuai dengan teori atau metode yang dipilih, aspek memeriksa kembali diukur melalui memeriksa kebenaran hasil yang diperoleh. Serta variasi jawaban siswa yang dimasud dalam kemampuan pemecahan masalah adalah kesistematisan jawaban, kelengkapan jawaban siswa dalam menuliskan jawaban dengan benar seluruh indikator pemecahan masalah dan banyaknya siswa menyelesaikan soal pemecahan masalah

\section{Metakognisi}

Pengertian Metakognisi

Istilah metakognisi pertama kali diperkenalkan oleh John Flavel pada tahun 1976. Defenisi Metakognisi berasal dari bahasa inggris yaitu Metacognition yang terdiri dari imbuhan "meta" dan "kognitif". Meta merupakan awalan untuk kognisi yang artinya "sesudah" kognisi. Penambahan awalah "meta" pada kognisi untuk merefleksikan ide bahwa metakognisi diartikan sebagai kognisi tentang kognisi, pengetahuan tentang pengetahuan atau berpikir tentang berpikir Chairani (2016). Sedangkan bagi John Flavel (1976), awalan ini digunakan untuk memperkenalkan istilah metamemori dalam penelitiannya tentang proses ingatan anak.

Menurut Anderson dan Krathwohl (2001: 214), penambahan awalan "meta" pada kata kognisi untuk merefeleksikan ide bahwa metakognisi adalah "tentang" atau "di atas" atau "sesudah" kognisi. Dengan demikian secara harfiah metakognisi diartikan sebagai kognisi tentang kognisi, pengetahuan tentang pengetahuan atau berpikir tentang berpikir. Di samping pengertian metakognisi sebagai berpikir tentang apa yang dipikirkan, terdapat peneliti yang menghubungkan istilah ini dengan pemikiran yang bersifat reflektif (desoete, 2001). Kata reflektif berasal dari kata "to reflect" artinya "to think about", sehingga dapat dikatakan bahwa pengertian metakognisi hampir sama dengan pengertian perefleksian terhadap apa yang dipikirkannya. Pengertian yang sama juga dikemukakan soedjadi (2004) bahwa berpikir reflektif lebih cenderung "kearah diri" atau lebih cenderung kearah metakognisi.

Schoenfeld (1992), mendefenisikan metakognisi sebagai berikut: "metacognition is thinking about our thingking and it comprises of the following three important aspects: knowledge about our own thought processes, control or self-regulation, and belief and 
Vol. 13, No.2, Desember 2020

intuition". Pengertian ini menunjukkan bahwa metakognisi diartikan sebagai pemikiran tentang pemikiran sendiri yang merupakan interaksi antara tiga aspek penting yaitu: pengetahuan tentang proses berpikir sendiri, pengontrolan atau pengaturan diri, serta keyakinan dan intuisi. Interaksi ini sangat penting karena pengetahuan tentang proses kognisi dapat membantu mengatur hal-hal di sekitar kita dan menyeleskai strategi-strategi untuk meningkatkan kemampuan metakognitif selanjutnya. Misalnya menyadari bahwa kita seirng lupa atau kurang memahami suatu konsep matematika dan sadar bahwa konsep tersebut lebih sulit dibandingkan dengan konsep yang lain, untuk itu perlu memilih cara tertentu (misalnya menggaris bawahi pengertian dari konsep tersebut) yang menurut kita lebih membantu memahami atau mengingat kembali apa yang lupa tadi.

Suherman (2003) menjelaskan bahwa metakognisi merupakan suatu kemampuan untuk menyadari apa yang siswa ketahui tentang dirinya sebagai pembelajar, sehingga ia dapat mengontrol serta menyesuaikan perilakunya secara optimal. Dengan kemampuan metakognisi, siswa dapat memiliki kemampuan yang tinggi dalam menyelesaikan masalah karena setiap langkah yang dikerjakan dapat menyadarkan proses berpikirnya, sheingga ia dapat memecahkan masalah secara optimal.

Taccasu (2008) mendefenisikan metakognisi sebagai bagian dari perencanaan, pemonitoringan, dan pengevaluasian proses belajar serta kesadaran dan pengontrolan proses belahar. Tim MKPBM (2001: 95) memandang metakognitif sebagai suatu kemampuan untuk melihat pada diri sendiri sehingga apa yang dia lakukan dapat terkontrol secara optimal. Para siswa dengan pengetahuan metakognitifnya sadar akan kelebihan dan keterbatasannya dalam belajar. Artinya saat siwa mengetahui kesalahannya, mereka sadar untuk mengakui bahwa mereka salah, dan berusaha untuk memeperbaikinya.

Berdasarkan pengertian diatas, maka dapat disimpulkan bahwa kemampuan metakognisi mengacu kepada pengetahuan atau kesadaran seseorang terhadap proses dan hasil berpikirnya. Metakgonisi berbeda dengan kognisi, misalnya keterampilan yang digunakan untuk membaca suatu teks berbeda dengan keterampilan memonitor pemahaman terhadap teks tersebut. Dimana metakognisi mempunyai kelebihan yakni seseorang mencoba merenungkan cara berpikir atau merenungkan proses kognitif yang dilakukannya. Dengan demikian aktivitas seperti merencanakan bagaimana pendekatan yang diberikan dalam tugastugas pembelajaran, memonitor kemampuan dan mengevaluasi rencana dalam rangka melaksanakan tugas merupakan sifat-sifat alami dari metakognisi.

Flavell (1976) mengartikan metakognisi sebagai berpikir tentang berpikirnya sendiri atau pengetahuan seseorang tentang proses berpikirnta. Sedangkan Lee dan Baylor (2006) mendefenisikan: metacognition as the ability to understand and monitorone's own thoughts and the assumption and implications of one's activities, yang berarti bahwa metakognisi sebagai kemampuan untuk memahami dan memantau berpikir diri sendiri dan asumsi serta implikasi dari kegiatan seseorang. Pendapat ini menekankan metakognisi sebagai kemampuan untuk memahami dan memantau kegiatan berpikir, sehingga proses metakognisi tiaptiap orang akan berbeda menurut kemampuannya.

Livingston (2012: 2), mendefenisikan metakognisi sebagai thinking about thingking atau berpikir tentang berpikir. Metakognisi, menurutnya adalah kemampuan berpikir dimana yang menjadi objek berpikirnya adalah proses berpikir yang terjadi pada diri sendiri. Sedangkan menurut Suherman (2003), metakognisi merupakan suatu kemampuan untuk menyadari apa yang siswa ketahui tentang dirinya sebagai pembelajar, sehingga ia dapat mengontrol serta menyesuaikan perilakunya secara optimal. Dengan kemampuan metakognisi, siswa dapat memiliki kemampuan yang tinggi dalam menyelesaikan masalah karena setiap langkah yang dikerjakan dapat menyadarkan proses berpikirnya, sehingga ia dapat memecahkan masalah secara optimal. Taccsu (2008), mendefenisikan metakognisi sebagai bagian dari perencanaan, pemonitoringan, dan pengevaluasian proses belajar serta kesadaran dan pngontrolan proses belajar.

Berdasarkan beberapa pendapat ahli tersebut, tampak bahwa tidak terdapat kesepakatan mengenai defenisi metakognisi secara formal. Disebabkan banyaknya jenis pengetahuan dan proses berbeda masuk dalam istilah metakognisi, tetapi secara umum terdapat suatu kesimpulan yang menghubungkan berbagai pendapat tersebut. Gambaran tentang perbedaan tersebut antara lain ditunjukkan oleh perbedaan pandangan dua orang pelopor studi tentang metakognisi yaitu Flavell dan Brown. Dimana Flavell cenderung memandang metakognisi dari aspek pengetahuan tentang kognisi seseorang, sementara Brown cenderung memandang metakognisi sebagai proses mengatur kognisi seseorang.

Namun meskipun Flavell dan Brown memiliki kecenderungan yang berbeda tentang metakognisi, tetapi keduanya berpandangan bahwa metakognisi mencakup dua aspek yang saling berkaitan satu sama lain. Flavell mengemukakan bahwa metakognisi terdiri dari (1) pengetahuan metakognitif (metacognitive knowledge), dan (2) pengalaman atau pengaturan metakognitif (metacognitive experience or regulation) (Flavell, 1979). Sedangkan Brown membagi metakognisi menjadi: (1) pengetahuan tentang kognisi (knowledge about cognition), dan (2) pengaturan kognisi (regulation of cognition). Metakognisi memiliki peran penting dalam pembelajaran matematika dan dalam pemecahan masalah matematika. Terkait dengan hal tersebut, metakognisi merupakan suatu kesadaran seorang siswa (awareness), pertimbangan (consideration), dan pengontrolan atau pemantauan terhadap strategi serta proses kognitif diri mereka sendiri. Pada prinsipnya usaha melibatkan metakognisi dalam berbagai kegiatan belajar diharapkan memberik manfaat untuk meningkatkan kualitas belajar yang dilaksanakan.

Kemampuan Metakognisi

Secara umum metakognisi memiliki komponen komponen yang disebut sebagai pengetahuan 
Vol. 13, No.2, Desember 2020

metakognisi dan pengalaman metakognisi.

Pengetahuan metakognisi adalah pengetahuan yang digunakan untuk mengarahkan proses berpikir kita sendiri. Menurut Chairani (2016) Pengarahan proses berpikir ini dapat dilakukan melalui aktivitas perenccanaan (planning), pemonitoran (monitoring), dan pengevaluasian (evaluating). Aktivitas-aktivitas ini disebut juga sebagai strategi metakognitif atau keterampilan metakognitif yang dapat membantu dalam menyelesaikan masalah yang dihadapi. Misalnya, dalam penyelesaian masalah matematika ketika pengetahuan metakognitif terhadap suatu tujuan tertantang maka akan melahirkan pengalaman metakognitif berupa perasaan sulit karena pencapaian tujuan tersebut tidak sesuai dengan apa yang diharapkan. Ketika menyadari tantangan tersebut dan pentingnya masalah tersebut diselesaikan, dan timbul kesadaran untuk menyelesaikan dengan mencari berbagai strategi, maka hal ini menunjukkan adanya pemanfaatn aktivitas metakognitif.

Dalam hubungannya dengan penyelesaian masalah matematika, beberapa penelitian seperti (Young \& King, 2006; Panoura, 2005; Gama; 2004) mengemukakan bahwa keberhasilan seseorang dalam menyelesaikan masalah turut dipengaruhi oleh aktivitas metakognisinya. Penyelesaian masalah dalam matematika merupakan suatu proses mental yang kompleks yang memerlukan visualisasi, imajinasi, manipulasi, analisis, abstraksi dan penyatuan ide. Dalam proses penyelesaian masalah matematika, terjadi interaksi antara aktivitas kognitif dan metakognitif. Aktivitas kognitif terbatas pada bagaimana informasi diproses untuk mencapai tujuan, sedangkan aktivitas metakognitif penekanannya pada kesadaran seseorang terhadap apa yang dilakukannya. Penyelesaian masalah akan diawali dengan bagaimana siswa mengenali masalah tersebut, misalnya dengan membangun representasi mental dari masalah yang dibaca, memutuskan bagaimana menyelesaikan masalah tersebut sampai dengan bagaimana mengevaluasi hasil yang dibuatnya.

Hubungan aktivitas kognitif dan metakognitif dikemukakan oleh Kayashima dan Inaba (2007) dalam suatu model yang disebut dengan aktivitas metakognitif selama berlangsungnya proses penyelesaian masalah. Model ini menggambarkan bagaimana aktivitas kognitif yang diawali dari mengobservasi masalah sampai dengan menemukan jawaban. Kemudian untuk membentuk aktivitas metakognitif pengajar perlu mengenali tujuan dan proses dari aktivitas kognitif. Selama proses penyelesaian masalah berlangsung, pengajar mengobservasi pemikirannya pada tataran kognitif untuk mengevaluasi proses tersbeut dan mengarahkan aktivitas kognitifnya. Ia mengevaluasi apakah proses penyelesaian masalah berjalan dengan baik atau tidak. Jika proses tersebut diputuskan "tidak baik", maka secara berhati-hati pengajar menjajaki kembalik aktivitas kognitifnya untuk memeriksa proses tersebut, dan meneliti ingatan jangka penjangnya untuk mendapatkan suatu informasi yang dapat digunakan untuk membuat penyelesainnya menjadi lebih baik.
Untuk mengetahui pemanfaatan aktivitas siswa dalam menyelesaikan masalah perlu dilakukan suatu analisis terhadap karakteristik-karakteristik metakognisi yang muncul ketika berlangsungnya proses penyelesaian masalah. Karakteristikkarakteristik tersebut dapat dianalisis atau dikontruksi melalui suatu kajian terhadap respon-respon yang diberikan siswa.

Dalam hubungannya dengan pembelajaran, Dawson \& Fucher (2008) mengemukakan bahwa siswa-siswa yang menggunakan metakognitifnya dengan baik akan menjadi pemikir yang kritis, problem solver yang baik, serta pengambil keputusan yang baik dari pada mereka yang tidak menggunakan metakognisinya. Disamping itu Marthan \& Koedinger (2005) menyatakan bahwa guru dapat meningkatkan penggunaan strategi metakognitif dalam membahas suatu konsep yang baru dengan mengingatkan kembali apa yang sudah diketahui siswa sebelumnya.

Metakognisi dalam Pembelajaran Matematika

Berdasarkan berbagai strategi pengembangan metakognisi di atas, maka salah satu strategi yang digunakan untuk membantu siswa dalam memahami suatu konsep matematika adalah dengan cara melihat buku catatan belajar siswa. Hal ini didasarkan juga pada kenyataan bahwa salah satu faktor kegagalan sebagian siswa adalah karena mereka tidak memiliki catatan tentang apa yang telah mereka pelajari.

Beberapa pertanyaan yang diminta untuk dijawab dalam catatan ketika mengakhiri pembelajaran adalah: materi apa yang baru saja anda pelajari, apakah anda mengerti semua materi tersebut, atau apakah ada materi yang tidak anda pahami, jika ada, tuliskan materi tersebut. Dari analisis terhadap beberapa jawaban yang tertulis dalam catatan, dikethaui bahwa ada kelompok siswa yang mengatakan memahami keseluruhan materi, ada yang mengemukakan bahwa mereka memahami sebagian tetapi tidak ada yang mengatakan tidak memahami sama sekali. Bagi mereka yang kurang memahami, mereka mengatakan bahwa mereka akan bertanya pada teman atau mencari sumber yang lain, mencoba mengerjakan tugas yang diberikan. Dari informasi yang tertulis, dapat dilihat beberapa indikator pemanfaatan metakognisi seperti pengetahuan tentang kelemahan diri sendiri dan memahami kelebihan orang lain, serta pengetahuan tentang tugas-tugas yang diberikan.

Dalam proses pembelajaran, pemanfaatan metakognisi dapat diketahui ketika siswa diberi kesempatan menyelesaikan masalah. Berikut salah satu contoh pemanfaatan metakognisi dalam menyelesaikan soal persamaan linear satu variabel. Diberikan soal berikut: Umur Rina 3 tahun lebih tua dari pada umur Jaka. Jika jumlah umur mereka adalah 27 tahun. Siapakah yang tertua antara Rina dan Jaka? (1) Apakah yang diketahui dan ditanyakan pada soal diatas? (2) Bagaimanakah cara mencari yang tertua antara Rina dan Jaka?, (3) Siapakah yang tertua antara Rina dan Jaka?

Sebelum siswa menyelesaikan permasalahan tersebut, mereka diminta untuk membaca sekitar 5 menit (tanpa menulis), kemudian untuk membantu 
siswa menyelesaikan masalah di atas, maka cobalah untuk menjawab pertanyaan metakognisi berikut ketika akan, sedang dan setelah memecahkan masalah.

Chairani (2016) mengemukakan tiga indikator yang terkait dengan kemampuan metakognisi, yaitu (a) kesadaran dalam mengembangkan rencana tindakan, (b) kesadaran dalam mengatur/memonitor rencana, dan (c) kesadaran dalam mengevaluasi rencana.

Dari analisis terhadap pekerjaan dan jawaban yang diberikan, akan diperoleh bahwa terdapat siswa yang menyadari bahwa mereka belum dapat menyelesaikan dengan baik, ada yang meyakini kebenaran pekerjaannya da nada ytang tidak meyakini kebenaran apa yang dikerjakannya. Hal ini menunjukkan bahwa secara tertulis aktifivitas metakognisi dapat terdeteksi, tetapi perlu dilanjutkan dengan wawancara secara mendalam. Hasil analisis menujukkan bahwa mereka yang memanfaatkan aktifitas metakognisinya dapat menyelesaikan masalah dengan baik.

Hal tersebut menunjukkan bahwa catatan belajar sebagai salah satu strategi yang digunakan untuk mengaktifkan metakognisi siswa dapat meningkatkan pemahamn terhadap materi yang dipelajari, sekaligus merupakan bahan bagi guru untuk merefleksikan diri baik dalam mempersiapkan bahan ajar maupun pengajaran yang dilakukan.

\section{Tingkat-Tingkat Metakognisi}

Metakognisi berkaitan dengan proses berpikir siswa tentang berpikrinya agar menemukan strategi yang tepat dalam memecahkan masalah. Keterampilan metakognisi sangat penting dalam memecahkan masalah matematika, sehingga keterampilan tersebut perlu ditingkatkan. Untuk meningkatkan keterampilan metakognisi diperlukan adanya kesadaran yang harus dimiliki siswa pada setiap langkah berpikrinya. Namun setiap siswa memiliki kemampuan yang berbeda-beda dalam menghadapi masalah. Berikut ini tingkat kesadaran siswa dalam berpikir ketika menyelesaikan suatu masalah oleh Swartz dan Perkins (Wulandari : 2018: 66), yaitu :

1. Tacit Use adalah penggunaan pemikiran tanpa kesadaran. Jenis pemikiran berkaitan dengan pengambilan keputusan tanpa berpikir tentang keputusan tersebut. Dalam hal ini, siswa menerapkan strategi atau keterampilan tanpa kesadaran khusus atau melalui coba-coba dan asal menjawab dalam memecahkan masalah.

2. Aware Use adalah penggunaan pemikiran dengan kesadran. Jenis pemikiran yang berkaitan dengan kesadaran siswa mengenai apa dan mengapa siswa melakukan pemikiran tersebut. Dalam hal ini, siswa menyadari bahwa ia harus menggunakan suatu langkah penyelesaian masalah dengan memberikan penjelasan mengapa ia memilih penggunaan langkah tersebut.

3. Strategic Use adalah penggunaan pemikiran yang bersifat strategis. Jenis pemikiran yang berkaitan dengan pengaturan individu dalam proses berpikirnya secara sadar dengan menggunakan strategi-strategi khusus yang dapat meingkatkan ketepatan berpikirnya. Dalam hal ini, siswa sadar dan memapu menyeleksi strategi atau keterampilan khusus untuk menyelesaikan masalah.

4. Reflective Use adalah penggunaan pemikiran yang bersifat reflektif. Jenis pemikiran yang berkaitan dengan refleksi individu dalam proses berpikirnya sebelum dan sesudah atau bahkan selama proses berlangsung dengan mempertimbangkan kelanjutan dan perbaikan hasil pemikirannya. Dalam hal ini siswa menyadari dan memperbaiki kesalahan yang dilakukan dalam langkah-langkah penyelesaian.

\section{Model Pembelajaran Berbasis Masalah}

Menurut Trianto (2009:91) bahwa "Pembelajaran berbasis masalah yang sering dikenal dengan Problem Based Instruction atau Problem Based Learning merupakan model pembelajaran yang menggunakan masalah sebagai titik tolak (starting point) pembelajaran". Masalah-masalah yang dapat dijadikan sebagai sarana belajar adalah masalah yang memenuhi konteks dunia nyata (real world) yang akrab dengan kehidupan sehari-hari para siswa.

Pada pembelajaran berbasis masalah siswa diminta untuk memecahkan masalah yang disajikan dengan menggali sebanyak mungkin informasi. Pengalaman ini sangat diperlukan dalam kehidupan sehari-hari dimana perkembangan pemikiran dan pekerjaan seseorang bergantung pada bagaimana dia mengajar dirinya sendiri. Menurut Eviyanti, Surya, Syahputra, dan Simbolon (2017:140) bahwa "intinya pada pembelajaran berbasis masalah adalah pembelajaran yang menggunakan masalah dunia nyata yang dipaparkan pada awal pembelajaran".

\section{Langkah-Langkah Model Pembelajan Berbasis} Masalah

Sebagaimana yang dijelaskan Trianto (2009:97) bahwa "dalam peran guru pada pembelajaran berbasis masalah sangat berbeda dengan peran guru pada pembelajaran konvensional". Ibrahim dan Nur (dalam Trianto, 2009:97) mengemukakan bahwa:

Secara garis besar pembelajaran berbasis masalah terdiri dari lima tahapan utama, dimulai dari guru memperkenalkan masalah kepada siswa, mengorganisasikan siswa untuk belajar (membantu siswa mendefinisikan masalah), membimbing investigasi yang dilakukan oleh siswa terhadap situasi masalah yang disajikan baik secara individu maupun kelompok, membantu siswa dalam mengembangkan dan menyajikan hasil kerjanya, kemudian menganalisis dan mengevaluasi proses penyelesaian masalah yang telah dilakukan.

Senada dengan hal tersebut Eviyanti (2017:140) mengemukakan bahwa:

Implementasi model pembelajaran berbasis masalah, yaitu: (1) orientasi masalah: pada tahap ini guru menjelaskan tujuan belajar dan memotivasi siswa, (2) mengatur siswa untuk belajar, (3) Memimpin penyelidikan siswa per individu atau perkelompok, (4) Mengembangkan dan menyajikan hasil pekerjaan, (5) menganalisis dan mengevaluasi proses pemecahan masalah. 


\section{METODE PENELITIAN}

Jenis penelitian ini adalah penelitian deskriptif kualitatif. Penelitian ini adalah jenis penelitian yang bertujuan untuk menggambarkan keterampilan metakognitif siswa dalam pemecahan masalah matematika dalam hal gaya belajar siswa. Subjek dalam penelitian ini melibatkan siswa kelas VII MTs Negeri 1 Labuhanbatu Selatan dengan 34 siswa. Pengangkatan mata pelajaran yang diwawancarai berdasarkan kacamata gaya belajar siswa dikelompokkan ke dalam empat kategori, yaitu 1) Teoris; 2) Pragmatis; 3) Reflektor; dan 4) Aktivis. Objek dalam penelitian ini adalah kemampuan metakognisi dalam pemecahan masalah dan gaya belajar siswa. Objek dalam penelitian ini dapat dilihat dari hasil tes kemampuan metakognisi dalam penyelesaian masalah yaitu melalui lembar jawaban siswa, gaya belajar siswa dapat dilihat dari angket gaya belajar siswa, aktivitas siswa dan prestasi belajar siswa pada setiap indikator keterampilan metakognitif. dalam pemecahan masalah matematis dilihat melalui lembar observasi kegiatan siswa dan melalui wawancara, yaitu transkrip tape-recorder siswa.

Analisis data yang digunakan dalam penelitian ini adalah analisis data kualitatif. Analisis kualitatif digunakan untuk menganalisis tingkat kemampuan metakognisi siswa dalam pemecahan masalah matematika, data angket gaya belajar siswa dan analisis lembar jawaban siswa dalam pemecahan masalah matematika dilihat dari gaya belajar. Langkah-langkah untuk menganalisis data Miles dan Huberman ditunjukkan dalam skema berikut (Sugiyono, 2016): 1 Yenode Pengumpulan - -I

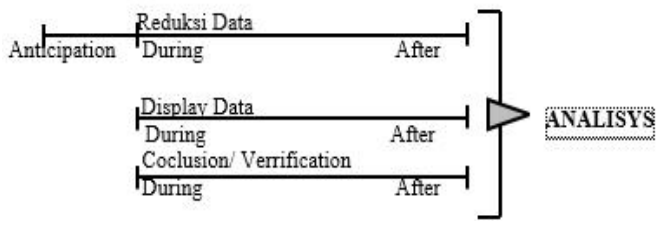

Gambar 1. Data Analysis Process

\section{Analisis Kemampuan Metakognisi Siswa dalam Pemecahan Masalah Matematika}

Penentuan standar minimum kemampuan pemecahan masalah matematika siswa berdasarkan (Kemdikbud, 2016) Kriteria Kelengkapan Minimum $(\mathrm{KKM}) \geq 65$. berdasarkan pandangan ini hasil tes kemampuan pemecahan masalah matematika siswa dapat disajikan dalam interval kriteria berikut: :

Tabel 1. Tingkat Pemecahan Masalah Matematika

\begin{tabular}{cc}
\hline $\begin{array}{l}\text { Tingkat Pemecahan } \\
\text { Masalah Matematis }\end{array}$ & Kategori \\
\hline $0 \leq$ SKPMM $<65$ & Rendah \\
\hline $65 \leq$ SKPMM $<80$ & Sedang \\
\hline $80 \leq$ SKPMM $<100$ & Tinggi \\
\hline
\end{tabular}

\section{Catatan:}

SKPMM = Skor Pemecahan Masalah Matematika

Untuk menentukan kriteria dan menganalisis data tes keterampilan metakognitif matematis siswa secara deskriptif, dan disajikan dalam interval kriteria pada tabel 2 .
Tabel 2. Interpretasi Tingkat Metakognisi Siswa

\begin{tabular}{lcc}
\hline No & Range of Stage & Level \\
\hline 1 & $3,41-4,00$ & Reflective Use \\
\hline 2 & $2,67-3,40$ & Strategic Use \\
\hline 3 & $1,33-2,66$ & Aware Use \\
\hline 4 & $0,00-1,32$ & Tacit Use \\
\hline
\end{tabular}

Informasi:

- Penggunaan Reflektif: adalah kriteria untuk jawaban siswa terhadap penggunaan pemikiran reflektif.

- Penggunaan Strategis: adalah kriteria untuk jawaban siswa dengan penggunaan pemikiran strategis

- Sadar Penggunaan: adalah kriteria untuk jawaban siswa terhadap penggunaan berpikir dengan kesadaran rendah

- Penggunaan Tacit: adalah kriteria untuk jawaban siswa terhadap penggunaan berpikir tanpa kesadaran

\section{HASIL PENELITIAN}

Deskripsi Pengelompokan Gaya Belajar

Berdasarkan hasil angket gaya belajar Honey \& Mumford yang dilakukan oleh 34 siswa kelas VII Tabligh MTs Negeri 1 Labuhanbatu Selatan, hasil gaya belajar ditunjukkan pada tabel 2 di bawah ini:

Tabel 3. Kuisioner Gaya Belajar Siswa Kelas VII Tabligh

\begin{tabular}{|c|c|c|}
\hline Learning Style & $\begin{array}{c}\text { Number of } \\
\text { Students }\end{array}$ & Percentage \\
\hline Activist & 4 Orang & $11,76 \%$ \\
\hline Reflector & 13 Orang & $38,23 \%$ \\
\hline Theorist & 10 Orang & $29,41 \%$ \\
\hline Pragmatic & 7 Orang & $20,58 \%$ \\
\hline
\end{tabular}

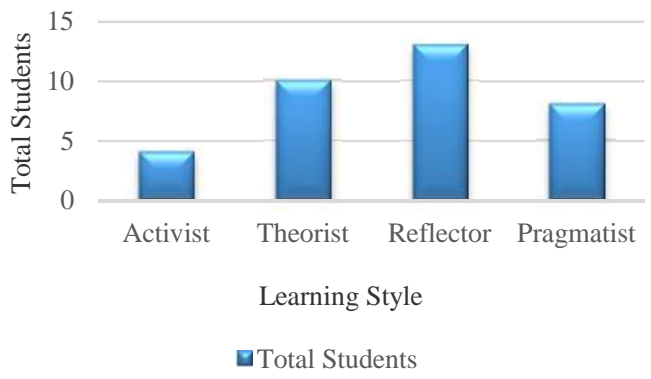

Gambar 2. Diagram Pengelompokan Gaya Belajar Kelas VII Tabligh

Berdasarkan Gambar. 2 dan Tabel. 1, kelas dominan dengan gaya belajar reflektor di mana situasi belajar, dia suka merefleksikan pengalaman dan mengamatinya dari berbagai sudut pandang dan mereka mengumpulkan data, baik secara langsung maupun dari orang lain, dan lebih suka memikirkannya secara menyeluruh sebelum sampai pada kesimpulan apa pun. (Honey \& Mumford, 1992). Hal ini sesuai dengan karakteristik pembelajaran berbasis masalah yaitu dalam kelompok, siswa dapat berperan langsung dalam 


\section{PARADIKMA JURNAL PENDIDIKAN MATEMATIKA}

Vol. 13, No.2, Desember 2020

pembelajaran dalam meningkatkan kemampuan metakognisi dalam menyelesaikan masalah matematika siswa.

\section{Tingkat Pemecahan Masalah Matematika Siswa}

Berdasarkan hasil tes pemecahan masalah matematika siswa dari 34 siswa, maka diperoleh tingkat pemecahan masalah matematika siswa yang tersebar di tiga tingkatan, dapat disajikan sebagai berikut:

Tabel 4. tingkat kemampuan pemecahan masalah matematika

\begin{tabular}{clccc}
\hline No & $\begin{array}{c}\text { Interval } \\
\text { Score }\end{array}$ & $\begin{array}{c}\text { Number of } \\
\text { Students }\end{array}$ & Percentage & Category \\
\hline 1 & $\begin{array}{l}0 \leq \text { SKPMM } \\
<65\end{array}$ & 14 People & $41,17 \%$ & Low \\
\hline 2 & $\begin{array}{l}65 \leq \text { SKPMM } \\
<80\end{array}$ & 15 People & $44,11 \%$ & Medium \\
\hline 3 & $\begin{array}{l}80 \leq \text { SKPMM } \\
\leq 100\end{array}$ & 5 People & $14,70 \%$ & High \\
\hline
\end{tabular}

Untuk memperjelas, tingkat pemecahan masalah matematika siswa dalam disajikan dalam bentuk diagram berikut:

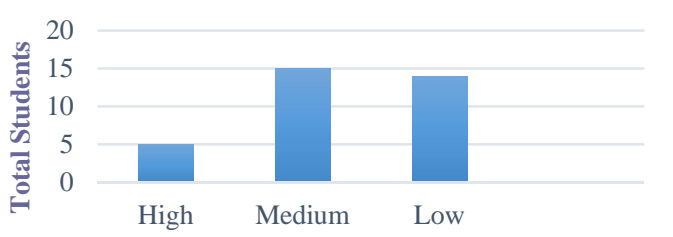

level of mathematical problem solving ability

Total Students Matematika Siswa Kelas VII di Tabligh MTs Negeri 1 Labuhanbatu Selatan

Berdasarkan Gambar 3 dan tabel 4 menunjukkan bahwa dari 34 siswa, proporsi tertinggi siswa dengan kemampuan sedang memiliki tingkat pemecahan masalah matematika tertinggi, diikuti oleh siswa berkemampuan rendah, dan siswa berkemampuan tinggi.

\section{Tingkat Kemampuan Metakognisi}

Keterampilan metakognisi siswa dalam menyelesaikan masalah matematika diperoleh dengan diberikan. Berdasarkan hasil tes diperoleh tingkat keterampilan metakognitif siswa, seperti yang disajikan dalam tabel 5 berikut:

Tabel 5. Tingkat Kemampuan Metakognisi Siswa

\begin{tabular}{clcc}
\hline No & $\begin{array}{c}\text { Metacognition } \\
\text { Level }\end{array}$ & $\begin{array}{c}\text { Number } \\
\text { of } \\
\text { Students }\end{array}$ & Percentage \\
\hline 1 & Reflective Use & 1 & $2,94 \%$ \\
\hline 2 & Strategic Use & 13 & $38,23 \%$ \\
\hline 3 & Aware Use & 12 & $35,29 \%$ \\
\hline 4 & Tacit Use & 8 & $23,53 \%$ \\
\hline
\end{tabular}

Hasil ini dapat disajikan dalam bentuk diagram pada gambar 4 . Berdasarkan gambar 4 tersebut, tingkat kemampuan metakognisi siswa di kelas VII Tabligh MTs Negeri 1 Labuhanbatu Selatan lebih dominan menggunakan sadar dan penggunaan strategis. Hal ini dapat dilihat ketika memecahkan masalah matematika,
Gambar 3. Diagram Tingkat Pemecahan Masalah melihat hasil keterampilan metakognitif yang

siswa dengan tingkat kesadaran penggunaan metakognisi menyadari bahwa ia harus menggunakan pemecahan masalah satu langkah dengan memberikan penjelasan mengapa ia memilih untuk menggunakan langkah-langkah ini. Siswa dengan penggunaan strategis keterampilan metakognitif, dalam hal ini dapat memilih strategi atau keterampilan khusus untuk memecahkan masalah.

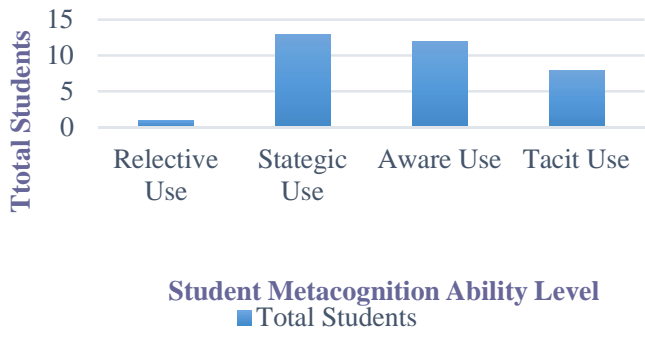

Gambar 4. Diagram Kemampuan Metakognisi Siswa

Deskripsi Tingkat Kemampuan Metakognisi dalam Pemecahan Masalah Matematika Siswa dalam hal gaya belajar

Untuk melihat tingkat kemampuan keterampilan metakognitif dalam memecahkan masalah matematika siswa dalam hal gaya belajar dilakukan dengan terlebih dahulu mengklasifikasikan hasil tes siswa sesuai dengan gaya belajar mereka, maka masing-masing gaya belajar akan dilihat levelnya dengan melihat skor total siswa. hasil tes pemecahan masalah dalam matematika siswa.

Deskripsi Tingkat Kemampuan Metakognisi dalam Pemecahan Masalah Matematika Siswa dengan Teori Gaya Belajar

Berdasarkan hasil pengelompokan gaya belajar siswa, siswa kelas VII Tabligh MTs Negeri 1 Labuhanbatu Selatan dengan gaya belajar teori terdiri dari 10 siswa. Berdasarkan hasil tes yang diberikan kepada siswa, tingkat kemampuan pemecahan masalah matematika yang diperoleh siswa dengan gaya belajar teori adalah seperti pada Tabel 6 berikut.

Tabel 6. Tingkat Pemecahan Masalah Matematika Siswa dengan Teori Gaya Belajar

\begin{tabular}{|c|c|c|c|c|}
\hline No & $\begin{array}{c}\text { Score } \\
\text { Interval }\end{array}$ & $\begin{array}{c}\text { Number } \\
\text { of } \\
\text { Students }\end{array}$ & Percentage & Category \\
\hline 1 & $\begin{array}{l}0 \leq \\
\text { SKPMM < } \\
65\end{array}$ & 6 People & $60 \%$ & Low \\
\hline 2 & $\begin{array}{l}65 \leq \\
\mathrm{SKPMM} \\
<80\end{array}$ & 4 People & $40 \%$ & Medium \\
\hline 3 & $\begin{array}{l}80 \leq \\
\text { SKPMM } \\
\leq 100\end{array}$ & - & $0 \%$ & High \\
\hline \multicolumn{5}{|c|}{$\begin{array}{l}\text { Tingkat pemecahan masalah matematika siswa } \\
\text { dengan gaya belajar teori tersebar di dua tingkat yang } \\
\text { dapat disajikan dalam gambar } 5 \text {. Dari } 11 \text { siswa dengan } \\
\text { gaya belajar teori, ternyata tingkat pemecahan masalah } \\
\text { matematika siswa dengan kemampuan rendah memiliki } \\
\text { proporsi tertinggi, diikuti oleh siswa dengan } \\
\text { kemampuan sedang, sedangkan untuk siswa }\end{array}$} \\
\hline
\end{tabular}

Analisis Kemampuan Metakognisi dalam Pemecahan Masalah Matematis pada Pembelajaran Berbasis Masalah Ditinjau dari Gaya Belajar Siswa 
Vol. 13, No.2, Desember 2020

berkemampuan tinggi tidak ada siswa yang termasuk dalam level ini.

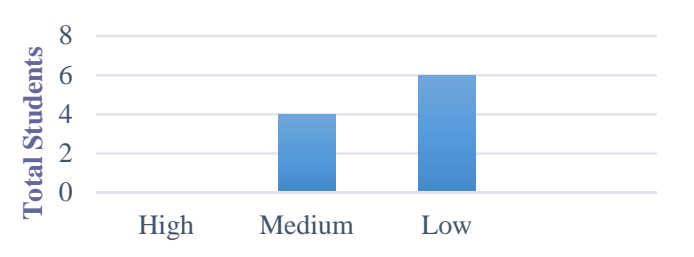

Levels of Student Problem Solving

$$
\text { m Total Students }
$$

Gambar 5. Diagram Tingkat Pemecahan Masalah Matematika Siswa dengan Gaya Belajar Teori

Untuk hasil tes keterampilan metakognitif siswa dengan gaya belajar teori, tingkat keterampilan metakognitif siswa diperoleh seperti yang disajikan dalam tabel berikut:

Tabel 7. Tingkat Kemampuan Metakognisi Siswa dengan Teori Belajar

\begin{tabular}{clcc}
\hline No & $\begin{array}{c}\text { Metacognition } \\
\text { Level }\end{array}$ & $\begin{array}{c}\text { Number } \\
\text { of } \\
\text { Students }\end{array}$ & Percentage \\
\hline 1 & Reflective Use & 0 & $0 \%$ \\
\hline 2 & Strategic Use & 2 & $20 \%$ \\
\hline 3 & Aware Use & 4 & $40 \%$ \\
\hline 4 & Tacit Use & 4 & $40 \%$ \\
\hline
\end{tabular}

Rincian lebih lanjut dapat diamati pada Gambar 6 . diagram tingkat keterampilan metakognitif dalam memecahkan masalah matematika siswa dengan gaya belajar Theorist.

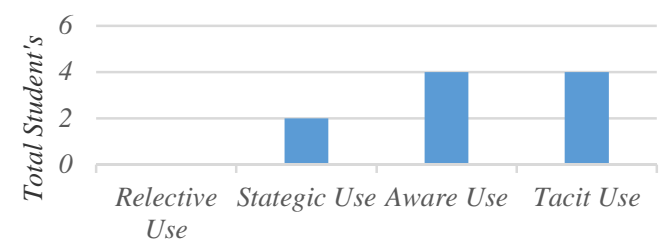

\section{Levels of Student Metacognition Ability} - Total Students

Gambar 6. Diagram Tingkat Kemampuan

Metakognisi dalam Pemecahan Masalah Matematika

Siswa dengan Gaya Belajar Teori

Berdasarkan Tabel 7 ditemukan bahwa tingkat kemampuan metakognisi siswa dalam memecahkan masalah matematika dengan gaya belajar teori dominan berada pada tingkat penggunaan sadar metakognisi. Dengan kata lain siswa dengan gaya belajar teori tidak berada dalam kategori tinggi dan dengan tingkat penggunaan reflektif metakognisi. Ini disebabkan oleh individu dengan gaya belajar teori ini yang lebih suka membaca sejalan dengan pendapat Honey \& Mumford (1992). Siswa dengan gaya belajar ini suka memahami teori sebelum melakukan suatu tindakan, dan cenderung membaca buku dan membuat keputusan berdasarkan teori. Jadi itu tidak memaksimalkan waktu dalam belajar mengasah kemampuan metakognisi dalam menyelesaikan masalah matematika.

\section{Deskripsi Tingkat Kemampuan Metakognisi dalam Pemecahan Masalah Matematika Siswa dengan Gaya Belajar Pragmatis}

Berdasarkan hasil pengelompokan gaya belajar siswa, siswa kelas VII Tabligh MTs Negeri 1 Labuhanbatu Selatan dengan gaya belajar pragmatik terdiri dari 8 siswa. Berdasarkan hasil tes siswa, tingkat kemampuan pemecahan masalah matematika siswa dengan gaya belajar pragmatis diperoleh seperti pada Tabel 8. berikut ini.

Tabel 8. Tingkat Pemecahan Masalah Matematika Siswa

\begin{tabular}{ccccc}
\hline No & $\begin{array}{c}\text { Score } \\
\text { Interval }\end{array}$ & $\begin{array}{c}\text { Number } \\
\text { of } \\
\text { Students }\end{array}$ & Percentage & Category \\
\hline 1 & $\begin{array}{l}0 \leq \text { SKPMM } \\
<65\end{array}$ & 3 People & $37,5 \%$ & Low \\
\hline 2 & $\begin{array}{l}65 \leq \text { SKPMM } \\
<80\end{array}$ & 3 People & $37,5 \%$ & Medium \\
\hline 3 & $\begin{array}{l}80 \leq S K P M M \\
\leq 100\end{array}$ & 2 People & $25 \%$ & High \\
\hline
\end{tabular}

Berdasarkan hasil tes pemecahan masalah matematika siswa yang telah dikelompokkan ke dalam masing-masing gaya belajar mereka, diperoleh sebanyak 8 siswa yang tergabung dalam gaya belajar pragmatis dan diperoleh tingkat pemecahan masalah matematika siswa yang tersebar menjadi tiga level. Diagram disajikan pada Gambar 7. sebagai berikut:

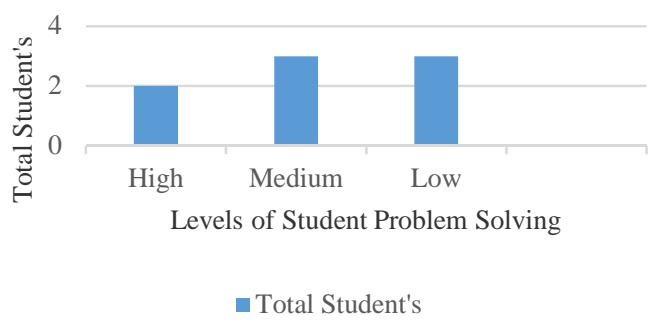

Gambar 7. Diagram Tingkat Pemecahan Masalah Matematika Siswa dengan Gaya Belajar Pragmatis

Dari 8 siswa, ternyata tingkat pemecahan masalah matematika siswa dengan gaya pragmatik kemampuan sedang dan rendah memiliki proporsi yang sama dengan siswa berkemampuan tinggi. Berdasarkan hasil tes keterampilan metakognitif dari suden dengan gaya belajar pragmatis, tingkat keterampilan metakognitif siswa diperoleh seperti yang disajikan dalam tabel berikut:

Tabel 9. Tingkat Kemampuan Metakognisi Matematika Siswa dengan Gaya Belajar Pragmatis

\begin{tabular}{clcc}
\hline No & $\begin{array}{c}\text { Metacognition } \\
\text { Level }\end{array}$ & $\begin{array}{c}\text { Number of } \\
\text { Students }\end{array}$ & Percentage \\
\hline 1 & Reflective Use & 1 & $12,5 \%$ \\
\hline 2 & Strategic Use & 3 & $37,5 \%$ \\
\hline 3 & Aware Use & 2 & $25 \%$ \\
\hline 4 & Tacit Use & 2 & $25 \%$ \\
\hline
\end{tabular}

Rincian lebih lanjut dapat diamati pada Gambar 8 diagram tingkat kemampuan metakognisi dalam pemecahan masalah matematika siswa dengan gaya belajar pragmatis. 


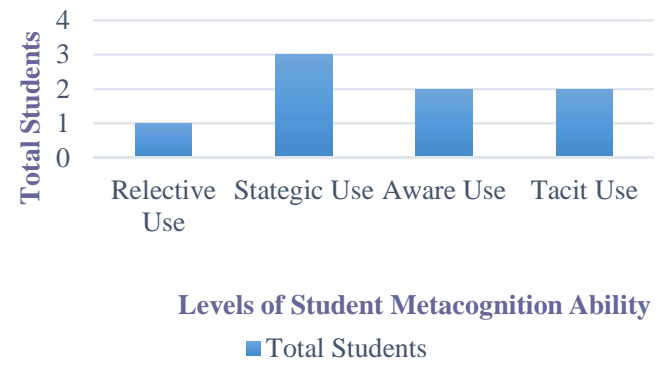

Gambar 8. Diagram Tingkat Kemampuan

Metakognisi dalam Pemecahan Masalah Matematika

Siswa dengan Gaya Belajar Pragmatis

Berdasarkan Tabel 9 Ditemukan bahwa tingkat kemampuan metakognitif dalam memecahkan masalah matematika siswa dengan gaya belajar pragmatik dominan adalah pada tingkat penggunaan strategis metakognisi. Dalam gaya belajar pragmatis ada siswa dengan kategori kemampuan tinggi dan ada siswa dengan karakteristik metakognisi penggunaan reflektif. Ini karena "dalam situasi belajar, yang terbaik adalah menemukan kegunaan praktis dari ide dan teori. Dia mampu memecahkan masalah dan membuat keputusan secara efektif" (Honey \& Mumford, 1992). Sehingga dengan mengoptimalkan gaya belajar selama pembelajaran dapat meningkatkan kemampuan metakognisi siswa dalam menyelesaikan masalah matematika.

Deskripsi Tingkat Kemampuan Metakognisi dalam Pemecahan Masalah Matematika Siswa dengan Gaya Belajar Reflektor

Berdasarkan hasil pengelompokan gaya belajar siswa, siswa kelas VII Tabligh MTs Negeri 1 Labuhanbatu Selatan dengan gaya belajar teori terdiri dari 13 siswa. Berdasarkan hasil tes keterampilan metakognitif dalam memecahkan masalah matematika siswa, tingkat keterampilan metakognitif yang diperoleh dalam memecahkan masalah matematika siswa dengan gaya belajar Reflektor seperti pada Tabel 10 berikut.

Tabel 10. Tingkat Pemecahan Masalah Matematika Siswa

\begin{tabular}{ccc}
\hline No & $\begin{array}{c}\text { Metacognition } \\
\text { Level }\end{array}$ & $\begin{array}{c}\text { Number } \\
\text { of } \\
\text { Students }\end{array}$ \\
\hline
\end{tabular}

\begin{tabular}{clcc}
\hline 1 & Reflective Use & - & $0 \%$ \\
\hline 2 & Strategic Use & 6 People & $46,15 \%$ \\
\hline 3 & Aware Use & 5 People & $38,46 \%$ \\
\hline 4 & Tacit Use & 2 People & $15,38 \%$ \\
\hline
\end{tabular}

Berdasarkan hasil tes pemecahan masalah matematika siswa yang telah dikelompokkan ke dalam masing-masing gaya belajar mereka. Kemudian diperoleh sebanyak 13 siswa yang tergabung dalam gaya belajar reflektor dan diperoleh tingkat pemecahan masalah matematika siswa yang tersebar di tiga tingkatan. Tingkat pemecahan maaslah matematis siswa disajikan pada diagram 9 .

Berdasarkan Gambar 9 Terlihat bahwa dari 13 siswa berkemampuan sedang memiliki proporsi tertinggi, diikuti oleh siswa berkemampuan rendah, dan siswa berkemampuan tinggi. Untuk hasil tes kemampuan metakognisi siswa dengan gaya belajar reflektor, tingkat keterampilan metakognitif siswa diperoleh, seperti yang disajikan dalam tabel 11 .

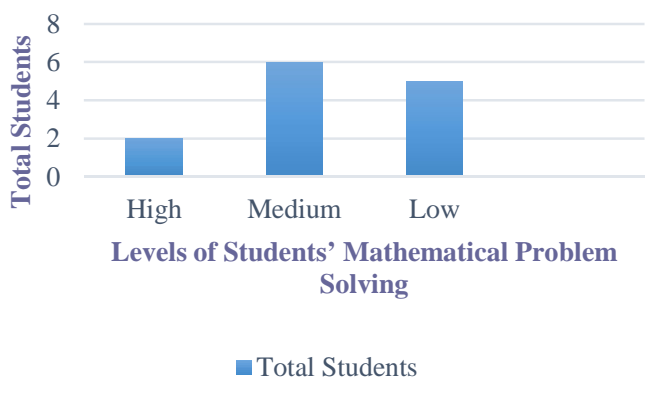

Gambar 9. Diagram Tingkat Pemecahan Masalah Matematika Siswa dengan Gaya Belajar Reflektor Tabel 11. Tingkat Kemampuan Metakognisi Matematika Siswa dengan Gaya Belajar Reflektor

\begin{tabular}{llcc}
\hline No & $\begin{array}{c}\text { Metacognition } \\
\text { Level }\end{array}$ & $\begin{array}{c}\text { Number } \\
\text { of } \\
\text { Students }\end{array}$ & Percentage \\
\hline 1 & Reflective Use & - & $0 \%$ \\
\hline 2 & Strategic Use & 6 People & $46,15 \%$ \\
\hline 3 & Aware Use & 5 People & $38,46 \%$ \\
\hline 4 & Tacit Use & 2 People & $15,38 \%$ \\
\hline \multicolumn{2}{l}{ Untuk melihat lebih }
\end{tabular}
Gambar 10 diagram tingkat keterampilan metakognitif dalam memecahkan masalah matematika siswa dengan gaya belajar reflector

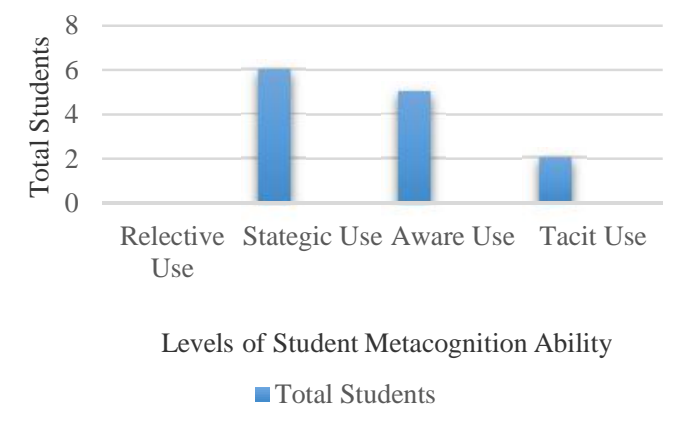

Gambar 10. Diagram Tingkat Kemampuan Metakognisi dalam Pemecahan Masalah Matematika Siswa dengan Gaya Belajar Reflektor

Berdasarkan Tabel 11 Ditemukan bahwa tingkat kemampuan metakognisi dalam menyelesaikan masalah matematika siswa dengan gaya belajar reflektor lebih dominan dan memiliki tingkat karakteristik penggunaan strategi metakognisi dengan tingkat kemampuan pemecahan masalah yang sedang. Dalam gaya belajar Reflektor ini terdapat siswa dalam kategori tinggi dan tidak ada siswa dengan karakteristik tingkat metakognisi penggunaan reflektif, hal ini disebabkan "dalam situasi pembelajaran, ia lebih suka bekerja dalam kelompok dan menerima umpan balik pribadi" (Honey \& Mumford, 1992). Hal ini sejalan dengan pembelajaran berbasis masalah yang belajar dalam kelompok sehingga siswa dapat berperan langsung dalam pembelajaran sehingga dapat meningkatkan kemampuan metakognisi dalam pemecahan masalah matematika. 
Vol. 13, No.2, Desember 2020

\section{Deskripsi Tingkat Kemampuan Metakognisi dalam \\ Pemecahan Masalah Matematika Siswa dengan Gaya Belajar Aktivis \\ Berdasarkan hasil pengelompokan gaya belajar} siswa, siswa kelas VII Tabligh MTs Negeri 1 Labuhanbatu Selatan dengan gaya belajar aktivis terdiri dari 3 siswa. Berdasarkan hasil tes yang diberikan kepada siswa, tingkat kemampuan pemecahan masalah matematika yang diperoleh siswa dengan gaya belajar aktivis adalah seperti pada Tabel 11. berikut ini.

Tabel 11. Tingkat Pemecahan Masalah Matematika Siswa dengan Gaya Belajar Aktivis

\begin{tabular}{clccc}
\hline No & Score Interval & $\begin{array}{c}\text { Number } \\
\text { of } \\
\text { Students }\end{array}$ & Percentage & Category \\
\hline 1 & $\begin{array}{l}0 \leq \mathrm{SKPMM}< \\
65\end{array}$ & - & $0 \%$ & Low \\
\hline 2 & $\begin{array}{l}65 \leq \mathrm{SKPMM}< \\
80\end{array}$ & 2 Orang & $66,67 \%$ & Medium \\
\hline 3 & $\begin{array}{l}80 \leq \mathrm{SKPMM} \leq \\
100\end{array}$ & 1 Orang & $33,33 \%$ & High \\
\hline
\end{tabular}

Tingkat pemecahan masalah matematika siswa dengan gaya belajar aktivis yang tersebar di dua tingkat, dapat disajikan dalam bentuk diagram berikut:

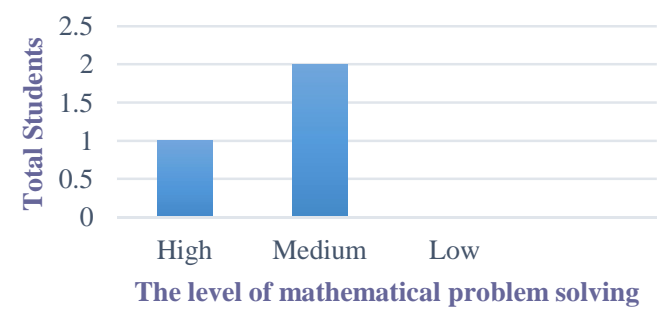

- Total Students

Gambar 11. Diagram Tingkat Pemecahan Masalah Matematika Siswa dengan Gaya Belajar Aktivis

Berdasarkan 3 siswa dengan gaya belajar aktivis, ternyata tingkat pemecahan masalah matematika siswa dengan gaya belajar aktivis berada pada kemampuan pemecahan masalah sedang. Untuk hasil tes keterampilan metakognitif siswa dengan gaya belajar aktivis tingkat keterampilan metakognitif siswa diperoleh, seperti yang disajikan dalam tabel berikut:

Tabel 12. Tingkat Kemampuan Metakognisi Siswa dengan Teori Belajar

\begin{tabular}{clcc}
\hline No & $\begin{array}{c}\text { Tingkat } \\
\text { Metakognisi }\end{array}$ & $\begin{array}{c}\text { Jumlah } \\
\text { Siswa }\end{array}$ & Presentase \\
\hline 1 & Reflective Use & 0 & $0 \%$ \\
\hline 2 & Strategic Use & 2 & $66,67 \%$ \\
\hline 3 & Aware Use & 1 & $33,33 \%$ \\
\hline 4 & Tacit Use & 0 & $0 \%$ \\
\hline Tingkat keterampilan & metakognitif dalam
\end{tabular}
memecahkan masalah matematika siswa dengan gaya belajar aktivis disajikan pada gambar 12. Berdasarkan Tabel 12 Ditemukan bahwa tingkat kemampuan metakognisi dalam memecahkan masalah matematika siswa dengan gaya belajar aktivis, berada pada tingkat penggunaan strategis metakognisi dan penggunaan sadar, dan berada pada kemampuan pemecahan masalah sedang dan tinggi. Ini karena siswa dengan gaya belajar aktivis melibatkan diri mereka sepenuhnya dalam pengalaman baru. Mereka berpikiran terbuka, tidak skeptis, dan cenderung antusias tentang sesuatu yang baru. Filosofi mereka adalah "Saya akan mencoba sesuatu sekali". Mereka cenderung bertindak terlebih dahulu dan mempertimbangkan konsekuensinya sesudahnya. Mereka cenderung mengembangkan tantangan baru tetapi bosan dengan aplikasi jangka panjang (Honey \& Mumford, 1992). Jadi mereka cenderung untuk menyelesaikan masalah atau kegiatan pemecahan masalah.

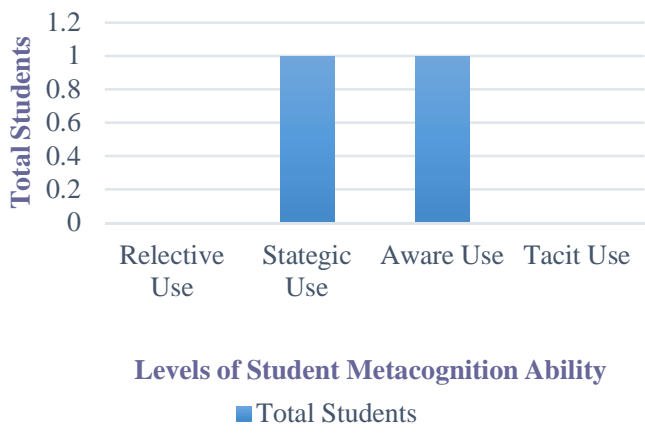

Gambar 12. Bagan Level Kemampuan Metakognisi dalam Pemecahan Masalah Matematika Siswa dengan Gaya Belajar Aktivis

Kesulitan dalam Metakognisi Matematika Siswa

Kesulitan metakognitif matematika yang dialami oleh siswa selama proses pembelajaran yang dilakukan dengan menggunakan model pembelajaran berbasis masalah adalah sebagai berikut:

Tabel 14. Kesulitan dalam Metakognisi Matematika Siswa

\begin{tabular}{|c|c|c|c|}
\hline No & $\begin{array}{c}\text { Difficulties } \\
\text { experienced } \\
\text { by students }\end{array}$ & Indicator & $\begin{array}{c}\text { Total } \\
\text { students }\end{array}$ \\
\hline 1 & Fact & $\begin{array}{l}\text { - Students cannot } \\
\text { interpret } \\
\text { mathematical } \\
\text { symbols or symbols } \\
\text { in problem solving. } \\
\text { - Students are not able } \\
\text { to understand the use } \\
\text { of mathematical } \\
\text { symbols in problem } \\
\text { solving. } \\
\text { - Students cannot } \\
\text { represent } \\
\text { mathematical } \\
\text { symbols to design } \\
\text { mathematical models } \\
\text { of a given problem. }\end{array}$ & 9 People \\
\hline 2 & Concept & $\begin{array}{l}\text { - Students are not able } \\
\text { to write concepts in } \\
\text { their own language } \\
\text { - Students are not able } \\
\text { to give examples and } \\
\text { not examples and } \\
\text { their reasons. } \\
\text { - Students are not able } \\
\text { to apply concepts in }\end{array}$ & $\begin{array}{c}11 \\
\text { People }\end{array}$ \\
\hline
\end{tabular}




\section{PARADIKMA JURNAL PENDIDIKAN MATEMATIKA}

Vol. 13, No.2, Desember 2020

\begin{tabular}{|c|c|c|c|}
\hline & & problem solving.. & \\
\hline 3 & Principle & $\begin{array}{l}\text { - Students are not able } \\
\text { to present steps in } \\
\text { problem solving in } \\
\text { an orderly and } \\
\text { correct way. } \\
\text { - Students are not } \\
\text { careful in presenting } \\
\text { problem solving } \\
\text { - Students are not able } \\
\text { to devise problem } \\
\text { solving strategies } \\
\text { effectively and } \\
\text { efficiently. }\end{array}$ & $\begin{array}{c}13 \\
\text { People }\end{array}$ \\
\hline 4 & Procedure & $\begin{array}{l}\text { - Students are not able } \\
\text { to use mathematical } \\
\text { formulas and rules in } \\
\text { solving problems. } \\
\text { - Students do not } \\
\text { connect the concepts } \\
\text { given to solve } \\
\text { problems. }\end{array}$ & $\begin{array}{c}21 \\
\text { People }\end{array}$ \\
\hline
\end{tabular}

Dari tabel ini, 9 siswa $(26,47 \%)$ mengalami kesulitan metakognitif dalam memahami fakta matematika. Sebanyak 11 orang $(32,35 \%)$ mengalami kesulitan dalam konsep, 13 orang (38, 23\%) mengalami kesulitan pada prinsipnya, dan 21 orang $(61,76 \%)$ mengalami kesulitan memahami prosedur.

\section{PEMBAHASAN}

Penelitian ini memfokuskan analisis pada keterampilan metakognitif siswa dalam memecahkan masalah matematika siswa dalam hal gaya belajar siswa. Masalah matematika adalah masalah intelektual, karena untuk dapat menyelesaikannya diperlukan kemampuan intelektual seseorang. Masalah matematika yang diberikan kepada siswa di sekolah, dimaksudkan untuk melatih siswa untuk mengembangkan kemampuan intelektual mereka dalam memahami, merencanakan untuk melakukan dan mendapatkan solusi untuk setiap masalah yang mereka hadapi. Dalam memecahkan masalah matematika, kemampuan metakognitif siswa juga berperan sehingga siswa dapat memikirkan ide-ide matematika dalam menyelesaikan masalah. Seperti Siagian, Sahat \& Bornok (2019), menyatakan bahwa kemampuan metakognisi juga memainkan peran dalam pemecahan masalah, sehingga siswa dapat memikirkan ide-ide matematika dalam memecahkan masalah matematika. Metakognisi juga merupakan proses di mana seseorang berpikir tentang berpikir untuk mengembangkan strategi untuk menyelesaikan masalah. Menurut Aljebri \& Gheith (2015) menyatakan bahwa metakognisi adalah berpikir tentang berpikir. Metakognisi adalah kemampuan di mana objek berpikir adalah proses berpikir yang terjadi dalam diri seseorang. Dalam hal ini, kemampuan metakognisi melibatkan pengetahuan dan kesadaran seseorang tentang aktivitas kognitifnya sendiri atau apa pun yang berkaitan dengan aktivitas kognitif.

Berdasarkan hasil penelitian, diperoleh bahwa 34 siswa kelas Tabligh VII, ada 3 siswa yang memiliki gaya belajar aktivis, 13 orang memiliki gaya belajar reflektor, 10 orang memiliki gaya belajar teori, dan 8 orang memiliki gaya belajar reflektor . Ini berarti bahwa keberadaan gaya belajar reflektor adalah yang paling dibandingkan dengan gaya belajar lainnya, maka posisi kedua adalah gaya belajar teori, posisi ketiga adalah gaya belajar pragmatis, dan yang terakhir adalah gaya belajar aktif. Hal ini didukung oleh hasil penelitian Arum (2016), bahwa "hasil analisis persentase gaya belajar mumfrod madu, dikatakan bahwa gaya belajar yang dominan adalah Gaya Belajar Reflektor 44,4\%, kemudian diikuti oleh Pragmatik $37,8 \%$, Teori 13,3\% dan akhirnya gaya belajar Aktivis $4.4 \%$ ". Dengan kata lain gaya belajar reflektor lebih dominan, sedangkan posisi kedua adalah gaya belajar pragmatis.

Hal ini juga didukung oleh hasil penelitian Zolghadri, Feyzollah, Ali, Nasram, Nasrollah \& Afshar (2015), yang didasarkan pada angket gaya belajar yang diberikan kepada siswa kelas XI MIA 1 SMAN 8 Surabaya, 16 siswa dipilih dengan gaya belajar dominan termasuk 1 gaya belajar aktivis siswa, 10 siswa belajar reflektor gaya, 3 gaya belajar pragmatis siswa, dan 2 anak berteori gaya belajar ". Hasil ini menunjukkan bahwa gaya belajar yang dominan adalah Reflektor, diikuti oleh Pragmatik, Ahli Teori dan aktivis.

Sebagaimana dijelaskan oleh Aljebri (2015) bahwa "kecenderungan siswa dengan gaya belajar reflektor menyiratkan bahwa mereka lebih suka mengamati dan berpikir tentang peristiwa yang terjadi. Mereka menghindari keterlibatan langsung dan lebih suka melihat apa yang terjadi dari sisi lain. Luangkan waktu belajar untuk melihat pengalaman dari berbagai perspektif, mengumpulkan data, dan menarik kesimpulan yang paling tepat. Zakirman (2017) menyatakan bahwa "orang-orang dengan gaya belajar reflektor memiliki peluang besar untuk mendapatkan dan memahami informasi yang sangat besar dan menggabungkannya dengan cara yang benar".

Tingkat Kemampuan Metakognisi Siswa dalam Pemecahan Masalah Matematika dalam Hal Gaya Belajar

Tingkat keterampilan metakognitif siswa dalam memecahkan masalah matematika siswa dengan gaya belajar aktivis

Siswa dengan tingkat pemecahan masalah yang tinggi dalam kategori gaya belajar aktivis berada pada tingkat metakognisi Penggunaan Strategis sebesar $33,33 \%$, yang berarti bahwa siswa memiliki kesadaran yang baik dalam beberapa tahap keterampilan metakognitif, yaitu siswa dapat menulis hal-hal yang diketahui dan hal-hal yang ditanyakan dengan benar dan benar. Siswa juga dapat merepresentasikan masalah ke dalam model matematika, siswa juga dapat memilih dan menerapkan strategi yang tepat dan benar untuk menyelesaikan masalah, dan melakukan perhitungan dengan benar dan dapat menyimpulkan solusi sesuai dengan masalah awal. Siswa dengan tingkat pemecahan masalah berada pada tingkat 
keterampilan metakognitif. Penggunaan Strategis dan penggunaan sadar, artinya 1 siswa memiliki kesadaran yang baik dalam beberapa tahap keterampilan metakognitif, yaitu siswa dapat menulis hal-hal yang diketahui dan hal-hal yang ditanyakan dengan benar dan benar. Siswa juga dapat merepresentasikan masalah ke dalam model matematika, siswa juga dapat memilih dan menerapkan strategi yang tepat dan benar untuk menyelesaikan masalah, dan melakukan perhitungan dengan benar dan dapat menyimpulkan solusi sesuai dengan masalah awal. Seorang siswa dengan tingkat penggunaan keterampilan sadar metakognisi menunjukkan bahwa siswa kurang memiliki kesadaran berpikir dalam kegiatan pemecahan masalah matematika.

Siswa dengan gaya belajar aktivis yang dominan berada pada level strategis menggunakan keterampilan metakognitif, yang berarti memiliki jenis pemikiran yang terkait dengan pengaturan individu dalam proses berpikir secara sadar dengan menggunakan strategi spesifik yang dapat meningkatkan akurasi pemikirannya. Di mana dalam penelitian ini siswa sadar dan mampu memilih strategi atau keterampilan khusus untuk memecahkan masalah. Siswa dengan gaya belajar aktivis diketahui bergaul dengan pengalaman baru dan menemukan kebahagiaan melalui dibimbing oleh pengalaman. Mereka lebih suka memproses masalah melalui brainstorming. Mereka juga cenderung terlibat dalam tantangan menggunakan pengalaman baru, dan mereka menghadapi kebosanan ketika datang ke prosedur. Moto mereka adalah, "Saya akan mencoba untuk mencoba". Siswa dengan gaya belajar ini cenderung kegiatan Pemecahan Masalah (Aljebri, 2015).

Tingkat keterampilan metakognitif siswa dalam memecahkan masalah matematika siswa dengan gaya belajar reflektor

Siswa dengan tingkat pemecahan masalah yang tinggi dalam kategori gaya belajar reflektor berada pada tingkat metakognisi Penggunaan Strategis sebesar $15,38 \%$, artinya siswa memiliki kesadaran yang baik dalam beberapa tahap keterampilan metakognitif, yaitu siswa dapat menulis hal-hal yang diketahui dan hal-hal yang diketahui. yang diminta dengan benar dan benar. Siswa juga dapat merepresentasikan masalah ke dalam model matematika, siswa juga dapat memilih dan menerapkan strategi yang tepat dan benar untuk menyelesaikan masalah, dan melakukan perhitungan dengan benar dan dapat menyimpulkan solusi sesuai dengan masalah awal. Siswa dengan tingkat pemecahan masalah berada pada level Strategic Use keterampilan metakognitif sebesar $15,38 \%$ dan $30,77 \%$, artinya siswa memiliki kesadaran yang baik dalam beberapa tahap keterampilan metakognitif, yaitu siswa mampu menulis hal-hal yang diketahui dan halhal yang diminta dengan benar dan benar. Siswa juga dapat merepresentasikan masalah ke dalam model matematika, siswa juga dapat memilih dan menerapkan strategi yang tepat dan benar untuk menyelesaikan masalah, dan melakukan perhitungan dengan benar dan dapat menyimpulkan solusi sesuai dengan masalah awal. Siswa dengan gaya belajar reflektor dengan tingkat pemecahan masalah yang rendah pada tingkat kemampuan metakognisi Aware Use sebesar 23,07\% dan penggunaan diam-diam sebesar $15,38 \%$. artinya sebanyak 6 siswa kurang memiliki kesadaran dalam pemecahan masalah matematika. Sedangkan 1 siswa tidak memiliki kesadaran dalam menyelesaikan masalah matematika.

Siswa dengan gaya belajar reflektor yang dominan berada pada tingkat keterampilan metakognitif Penggunaan Strategis, yang berarti siswa dengan gaya belajar reflektor memiliki jenis pemikiran yang terkait dengan regulasi individu dalam proses pemikiran mereka secara sadar dengan menggunakan strategi khusus yang dapat meningkatkan akurasi keterampilan mereka. berpikir. Dimana dalam penelitian ini siswa dengan gaya belajar reflektor sadar dan dapat memilih strategi atau keterampilan khusus untuk memecahkan masalah. Ini diperkuat oleh Aljebri (2015) bahwa orang-orang dengan gaya belajar reflektor, lebih suka berdiri di belakang pengalaman, mengumpulkan informasi, dan menaruh perhatian besar pada informasi rinci sebelum mengeluarkan generalisasi dan kesimpulan. Mereka cenderung tidak langsung mengambil kesimpulan atau mengambil keputusan sampai mereka memiliki bukti dan bukti yang diperlukan. Mereka cenderung mengamati orang lain dan tetap di latar belakang untuk melihat, mengamati, dan mempertimbangkan masukan orang lain.

Tingkat keterampilan metakognitif siswa dalam memecahkan masalah matematika siswa dengan gaya belajar pragmatis

Siswa dengan tingkat pemecahan masalah yang tinggi dalam kategori gaya belajar pragmatis berada pada tingkat kemampuan metakognitif penggunaan reflektif $12,5 \%$ dan penggunaan strategis $37,5 \%$, artinya siswa memiliki kesadaran yang baik dalam beberapa tahap keterampilan metakognitif, yaitu siswa mampu untuk menulis hal-hal yang diketahui dan ditanyakan dengan benar. Siswa dengan tingkat pemecahan masalah sadar menggunakan tingkat kemampuan metakognisi $25 \%$, yang berarti bahwa siswa kurang memiliki kesadaran dalam pemecahan masalah matematika. Siswa dengan tingkat penyelesaian masalah yang rendah pada tingkat diamdiam menggunakan tingkat kemampuan metakognisi $25 \%$, itu berarti siswa tidak menggunakan pemikiran kesadaran dalam pemecahan masalah matematika.

Siswa dengan gaya belajar pragmatis dominan di tingkat strategis menggunakan keterampilan metakognitif. Dengan kata lain siswa dengan gaya belajar ini, siswa menyadari bahwa ia harus menggunakan langkah pemecahan masalah dengan memberikan penjelasan mengapa ia memilih untuk menggunakan langkah-langkah ini. Ini diperkuat oleh Aljebri (2015) yang menyatakan bahwa "Pragmatik adalah individu yang ditandai oleh upaya mereka untuk menghasilkan ide, teori, dan aplikasi untuk mengujinya dalam kenyataan dengan cara yang positif dan praktis. Mereka memanfaatkan semua peluang untuk mencoba sesuatu dalam situasi yang praktis dan dapat diterapkan, dan cenderung tidak sabar dalam diskusi yang panjang. Moto filosofis mereka adalah "Selalu 
ada cara yang lebih baik" dan "Jika berhasil, itu baik", dan siswa dengan gaya belajar ini sangat cocok untuk pemecahan masalah matematika .

Tingkat keterampilan metakognitif siswa dalam memecahkan masalah matematika siswa dengan gaya belajar Theoris

Siswa dengan tingkat pemecahan masalah berada pada tingkat keterampilan metakognitif dari penggunaan strategis dan penggunaan sadar, masingmasing sebesar $20 \%$ dan $20 \%$, yang berarti bahwa siswa memiliki kesadaran yang cukup dalam beberapa tahap keterampilan metakognitif, yaitu siswa dapat menulis informasi dari pertanyaan dalam bentuk halhal yang diketahui dan ditanyakan dengan tepat dan benar, siswa juga dapat mewakili masalah ke dalam model matematika mereka, siswa juga dapat memilih dan menerapkan strategi yang tepat untuk menyelesaikan masalah, tetapi kekurangannya adalah bahwa siswa belum melakukan perhitungan dengan benar dan benar. Siswa dengan gaya belajar teori dengan tingkat pemecahan masalah yang rendah pada tingkat Tacit, menggunakan kemampuan metakognisi sebesar $40 \%$, itu berarti siswa tidak menggunakan kesadaran saat memecahkan masalah matematika. Siswa yang berada di level keterampilan metakognisi sadar menggunakan dan penggunaan diam-diam berada di posisi tertinggi yaitu sebesar $40 \%$, kemudian diikuti oleh siswa yang berada di level keterampilan metakognitif menggunakan dan menggunakan penggunaan diam-diam.

Dengan kata lain, siswa dengan gaya belajar teori ini terutama menyadari tingkat penggunaan metakognisi, yang berarti bahwa siswa dengan gaya belajar teori tidak menyadari bahwa mereka harus menggunakan langkah pemecahan masalah dengan tidak memberikan penjelasan dalam menyelesaikan masalah. . Hal ini diperkuat oleh Arum (2016) yang menyatakan bahwa ahli teori individu dalam kegiatan belajar mereka suka memahami teori sebelum mengambil tindakan, dan cenderung membaca buku dan membuat keputusan berdasarkan teori.

Jenis kesulitan yang dialami oleh siswa dalam memecahkan masalah matematika dalam hal gaya belajar

Berdasarkan temuan mengenai kesulitan metakognitif siswa kelas VII MTs Negeri 1 Labuhanbatu Selatan, ditemukan bahwa jenis kesulitan yang dialami siswa dalam memecahkan masalah matematika adalah 9 kesulitan faktual sebesar 26,47\%, 11 orang $(32,35 \%)$ ) mengalami kesulitan Konsep, siswa yang mengalami kesulitan prinsip adalah 13 orang $(38,23 \%)$, dan siswa yang mengalami kesulitan prosedural adalah 21 orang $(61,76 \%)$.

\section{KESIMPULAN}

Berdasarkan hasil analisis dan diskusi dalam bab IV dalam hal gaya belajar, beberapa kesimpulan diperoleh yang merupakan jawaban atas pertanyaan yang diajukan dalam pernyataan masalah. Kesimpulan ini adalah:
1. Tingkat kemampuan metakognisi 34 siswa dalam pemecahan masalah matematika dalam hal gaya belajar adalah sebagai berikut:

a. Siswa dengan gaya belajar reflektor pada tingkat strategis menggunakan keterampilan metakognitif memiliki kemampuan pemecahan masalah yang tinggi dan sedang. Pada tingkat kemampuan metakognisi, penggunaan sadar memiliki kemampuan pemecahan sedang. Pada tingkat keterampilan metakognitif, penggunaan diam-diam memiliki kemampuan pemecahan masalah yang rendah.

b. Siswa dengan gaya belajar reflektor pada tingkat strategis menggunakan keterampilan metakognitif memiliki kemampuan pemecahan masalah yang tinggi dan sedang. Pada tingkat kemampuan metakognisi yang sadar digunakan siswa memiliki kemampuan pemecahan sedang.

c. Siswa dengan gaya belajar pragmatis di tingkat keterampilan metakognitif reflektif dan penggunaan strategis memiliki kemampuan pemecahan masalah yang tinggi. Pada tingkat kemampuan metakognisi, penggunaan sadar memiliki kemampuan pemecahan masalah yang sedang. Pada tingkat keterampilan metakognitif penggunaan diamdiam siswa memiliki kemampuan pemecahan masalah yang rendah.

d. Siswa dengan gaya belajar teori pada tingkat keterampilan metakognisi sadar menggunakan memiliki kemampuan pemecahan masalah yang sedang. Pada tingkat keterampilan metakognitif, penggunaan diam-diam memiliki kemampuan pemecahan masalah yang rendah.

e. Siswa dengan gaya belajar aktivis pada tingkat kemampuan metakognisi strategic use memiliki kemampuan pemecahan masalah sedang. Pada tingkat kemampuan metakognisi aware use dan tacit use memiliki kemampuan pemecahan rendah.

2. Kesulitan metakognisi yang dialami siswa dengan gaya belajar pragmatis, reflektor, dan teoris dalam pemecahan masalah matematis adalah:

a. Kesulitan fakta, yakni merepresentasikan symbol-simbol matematika untuk merancang model matematika dari masalah yang diberikan.

b. Kesulitan konsep, yaitu kesulitan dalam mengaplikasikan metode substitusi, eliminasi, metode campuran, dan metode determinan untuk menyelesaikan masalah.

c. Kesulitan prinsip, yaitu kesulitan dalam menerapkan rumus-rumus serta aturan-aturan matematika serta kesulitan dalam menghubungkan konsep-konsep yang diberikan untuk menyelesaikan masalah.

d. Kesulitan prosedur, yaitu kesulitan dalam menyajikan langkah-langkah pemecahan masalah secara runtun dan benar, 
ketidaktelitian dalam penyajian pemecahan masalah, serta kesulitan dalam menyusun strategi pemecahan masalah secara efektif dan efisien.

\section{REFERENSI}

Alzahrani, K. S., Metacognition and Cooperative Learning in the Mathematics Classroom. International Electronic Journal Of Mathematics Education, 12(3): 475-491. 2017.

Anderson, O.W. \& Krathwohl, D.R., A Taxonomy For Learning, Teaching, and Assessing (A Revision of Bloom's Taxonomy of Educational Objectives). New York: Addision Wesley Longman, Inc. 2001.

Aljebri, N. M., \& Gheith. E., University Students' Level of Metacognitive Thinking and their Ability to Solve Problems. American International Journal of Contemporary Research, 5(3), 121-134. 2015.

Aljebri, N. M., \& Gheith. E., University Students' Level of Metacognitive Thinking and their Ability to Solve Problems. American International Journal of Contemporary Research, 5(3), 121-134. 2015.

Arum, S. Z. P., Profil Pemecahan Masalah Matematika Siswa Sma Ditinjau Dari Gaya Belajar Model Honey-Mumford. MATHEdunesa Jurnal Ilmiah Pendidikan Matematika. 3(5). 2016.

Amalia, E., Surya, E., \& Syahputra, E. (2017). The Effectiveness Of Using Problem Based Learning (PBL) in Mathematics Problem Solving Ability For Junior High School Students. International Journal Of Advance Research and Innovative Ideas in Education (IJARIIE). Vol. 3, Issue-2

Chatib, M., Orangtuanya Manusia: Melejitkan Potensi dan Kecerdasan dengan Menghargai Fitrah Setiap Anak. Bandung: PT Mizan Pustaka. 2014.

Carns, A.W. \& Carns, M.R., Teaching Study Skills, Cognitive Strategiesand School Metacognitive Skills through Self-Diagnosed Learning Styles. Counselor. 38(5): 341- 346. 1991.

Dawson, T., \& Fucher, K. (2008). Metacognition and Learning Adulthood. Contemporary Education Psychology, 11(1), 233-236.

Flavell, J.H. (1979). "Metacognition and Cognition Monitoring. A New area of CognitiveDevelopmental Inquiry". In Nelson, Thomas O.1992. Metacognition, core Reading, 3-8.: Allyn And Bacon. Boston

Honey, P. \& Mumford, A., The Manual of Learning Styles (3rd ed.). Peter Honey Publications Ltd, Maidenhead. 1992.

Kayashima, M., \& Inaba, A. (2007). The Model of Metacognitive Skill and How to Facilitate Development of the Skill, Faculty of Arts and Education, Tamagawa University. Japan.

Karatas, I \& Baki, A. The Effect of Learning Environments Based on Problem Solving on Students' Achievements of Problem Solving. International Electronic Journal of Elementary Education. 5 (3) : 249 - 268. Agustus 2017
Kemdikbud., Permendikbud No. 64 Tahun 2013 tentang Standar Isi Pendidikan Dasar dan Menengah. Jakarta: Kemdikbud. 2016.

Marthan, S., \& Koedinger, K., (2005). Fostering the Intelligent novice: Learning from Error with Metacognitive Tutoring, Educational Psychology, 89(4): 686-695.

Mulyono \& Hadiyanti., R., Analysis of mathematical problem-solving ability based on metacognition on problem-based learning. International Conference on Mathematics, Science and Education (ICMSE). $\begin{array}{lllll}\text { Series } & 983 & \text { (2018). } & 1-6 . & 2018 .\end{array}$ https://doi.org/10.1088/1742-6596/983/1/012157

Nugrahaningsih, T. A. (2011). Pemanfaatan Metakognisi dalam Pemecahan Masalah Matematika Siswa SMS. Disampaikan pada Seminar Nasional 91 Matematika dan Pendidikan Matematika, Universitas Widya Dharma Klaten.

Nurdin, M., \& Hamzah (2012) Belajar Dengan Pendekatan PAILKEM: Pembelajaran Aktif, Inovativ, Lingkungan, Kreatif, Efektif, Menerik. Jakarta. PT Bumi Aksara.

Polya. (1985). How to Solve It A New Aspect of Mathematical Method", New Jersey: Pearson Education, Inc, 1985.

Rawa, N. R., Tingkat Metakognisi Mahasiswa Program Studi Pgsd Pada Pemecahan Masalah Matematika Ditinjau Dari Gaya Belajar Introvert-Extrovert. Jurnal Tunas Bangsa. 4 (2). 2017.

Rahmawati, K. D., dkk., Analisis Kemampuan Metakognisi Siswa dalam Menyelesaikan Soal Cerita Matematika Berbasis Polya Subpokok Bahasan PLSV Kelas VII-A SMP Negeri 3 Jember. Artikel Ilmiah Mahasiswa. 2015.

Saragih, S., \& Napitupulu, E., Developing StudentCentered Learning Models to Improve High Order Mathematical Thinking Ability. International Education Studies, 8(6). 104-112. May, 2015. https://doi.org/10.5539/ies.v8n6p104

Syahputra, E., Panjaitan, E., Surya, E., Lubis, J.N. (2017). Analysis Mathematical Problem Solving Skills of Student of the Grade VIII-2 Junior High School Bilah Hulu Labuhan Batu. International Journal of Novel Research in Education and Learning. 4(2): 131-137

Syam, S., Ulfiani, R., \& Nursalam., Pengaruh Pengetahuan Metakognisi Dan Gaya Belajar Visual Terhadap Kemampuan Pemecahan Masalah Matematika Siswa Kelas Ix Smp Negeri 2 Barombong Kabupaten Gowa. Jurnal Matematika dan Pembelajaran, 4 (2): 231-244. 2016.

Siagian, M. V., Sahat. S., \& Bornok. S., Development of Learning Materials Oriented on Problem-Based Learning Model to Improve Students' Mathematical Problem Solving Ability and Metacognition Ability. International Electronic Journal Of Mathematics Education. 14(2), 331-340. 2019. https://doi.org/10.29333/iejme/5717

Suyono, \& Hariyanto., Belajar dan Pembelajaran. Surabaya: Remaja Rosdakarya. 2015.

Sugiyono., Metode Penelitian Kuantitatif, Kualitatif, Dan R\&D. Bandung: Penerbit Alfabeta. 2016. 
Vol. 13, No.2, Desember 2020

Schoenfeld, A.H. 1992. Learning to Think Mathematically Problem Solving Meta Cognition and Sense- Making in Mathematics. Handbook for Research on Mathematics Teaching and Learning . New York : MacMillan

Suherman, E. dkk (2003) Strategi Pembelajaran Matematika Kontemporer. Bandung: PT Remaja Rosdakarya.

Tim MKPBM Jurusan Pendidikan Matematika. (2001). Strategi Pembelajaran Kontemporer. Bandung: JICA.

Wardhani, S., dkk (2010). Pembelajaran Kemampuan Pemecahan Masalah Matematika di SD. Yogyakarta: PPPPTK.

Wulandari, T. (2018). Analisis Kemampuan Metakognisi Siswa Dalam Pemecahan Masalah Matematis Pada Pembelajaran Berbasis Masalah Di Sma Negeri 1 Binjai, Tesis. Universitas Negeri Medan.

Yeni, E. M., Kesulitan Belajar Matematika Di Sekolah Dasar. JUPENDAS, 2(2): 1-10. 2015.

Zulyanty, M., Ipung.Y., \& Makbul. M., Metakognisi Siswa Dengan Gaya Belajar Introvert Dalam Memecahkan Masalah Matematika. Jurnal Kajian Pembelajaran Matematika, 1 (1): 64-71. 2017.

Zakirman., Pengelompokkan Gaya Belajar Mahasiswa Menurut Teori Honey Mumford Berdasarkan Intensitas Kunjungan Pustaka. Jurnal Bimbingan dan Konseling. 4(1), 1-74. 2017.

Zolghadri, P., Feyzollah. S., Ali. T., Nasram. S., Nasrollah. V., \& Afshar. R., On the Role of Learning Styles Components (Objective, Experience, Reflective Observation, Abstract, Conceptualization, and Active Experimentation) on Studens's Mathematics Performance. American Journal of Educational Research, 2015, 3(9), 1142 1148. 2015. https://doi.org/0.12691/education-3-912. 